\title{
MACROECONOMIC STABILIZATION \\ IN LATIN AMERICA: RECENT \\ EXPERIENCE AND SOME \\ SEQUENCING ISSUES
}

Sebastian Edwards

Working Paper No. 4697

\section{NATIONAL BUREAU OF ECONOMIC RESEARCH \\ 1050 Massachusetts Avenue \\ Cambridge, MA 02138 \\ April 1994}

Financial support from the Institute for Policy Reform is gratefully acknowledged. The paper summarizes and draws partially from some of the work on Latin America I have undertaken in the last few years. I am grateful to Fernando Losada for efficient assistance. This paper is part of the NBER's research programs in International Finance and Macroeconomics and International Trade and Investment. Any opinions expressed are those of the author and not those of the National Bureau of Economic Research. 


\section{MACROECONOMIC STABILIZATION \\ IN LATIN AMERICA: RECENT \\ EXPERIENCE AND SOME \\ SEQUENCING ISSUES}

\section{ABSTRACT}

This paper reviews the experience of Latin American countries with structural reforms, and discusses the relationship between macroeconomic stabilization and trade liberalization programs undertaken in the region since the early 1980 s.

The problem of sequencing of stabilization and structural reforms is analyzed with detail: first from a theoretical perspective; second, reviewing the stabilization programs implemented in Latin America on a case by case basis. Particular emphasis is given to the analysis of the fiscal consequences of the chosen sequencing, as well as its impact on the evolution of domestic savings and investment, and on foreign investment.

The final part of the paper concentrates on the behavior of real exchange rates during the stabilization programs and its relationship with trade reforms.

Sebastian Edwards

The World Bank

1818 H Street

Washington, D.C. 20433

and NBER 
I.- Introduction

The debt crisis generated serious economic dislocations throughout the Latin American region. Even those countries that had traditionally followed exemplary macroeconomic policies and had experienced low inflation rates, suffered very rapid price increases after 1982. Balance of payment deficits soared and, in most countries, the foreign debt burden virtually paralyzed investment. Growth became negative and real wages plummeted. In spite of early signs that the macroeconomic disequilibria had become extremely serious, many analysts argued that the crisis was a mere short-run liquidity problem, that could be solved through (minor) debt restructuring and new monies.'

During the early years of the crisis, a number of countries - most notably Argentina (Austral Plan), Brazil (Cruzado Plan) and Peru (APRA Plan) - tried to solve their problems by implementing traditional policies based on increased controls, heightened protectionism and a higher degree of government involvement in economic matters. As time passed, however, it became increasingly apparent that these programs - sometimes referred to as heterodox programs - had badly failed. They generated run-away inflation, further declines in real wages, and prolonged stagnation.

Towards the late 1980s, and in part as a result of these failures, a new consensus on economic policy began to emerge in Latin America. At that time, an increasing number of Latin American leaders began to agree that the region was facing a serious crisis and that the transition to the 21 st century required major economic reforms. Politicians that for decades had advocated an increased involvement of the state in everyday economic life, began to argue in favor of macroeconomic stability, international openness, privatization and a greater role for market forces.

In the mid- to late-1980s most of the Latin American nations faced an array of macroeconomic and structural (microeconomic) problems. At the macro level there were three fundamental issues: First, there was a need to reduce, on permanent bases and in an

1 Early on both the World Bank and the IMF argued that the Latin American countries could "grow out" of the problem, without any need for implementing debt reduction programs (IMF, 1985). 
efficient way, the gap between aggregate expenditure and income. Second, inflation, which had jumped dramatically after 1982, had to be lowered to "reasonable" levels." And third, it was necessary to generate a stable macroeconomic environment conducive to the resumption of growth. At the structural level there was a clear need to greatly deregulate markets - including the capital market -, reduce protection, and embark on a broad privatization scheme. These reforms were seen as necessary to compete internationally and regain growth through exports expansion.

From early on a preoccupation of many analysts referred to defining the most appropriate sequence of stabilization and structural reforms. Should both broad reform processes proceed simultaneously, or was a specific order preferable on efficiency grounds? A particularly pressing question was that related to the relationship between the opening of international trade - seen by many as the corner stone of the micro reforms - and antiinflationary policies. Should import tariffs be lowered early on in the reform program, or should (a minimal degree of) macroeconomic stability be achieved before turning towards trade liberalization? More recently these issues have become important in other parts of the world, where a number of countries have been embarked on major reform efforts. This has been particularly the case in Central and Eastern Europe, where policy makers are facing both highly distorted microeconomic structures - including severely distorted international trade regimes --, as well as severe macroeconomic disequilibria.

This paper analyzes the recent implementation of macroeconomic stabilization programs in Latin America, and discusses their relationship with the trade liberalization reforms undertaken in the region during the last decade. The paper is organized as follows: In section II the policy literature on the relationship between macroeconomic stabilization and structural reforms is briefly analyzed. It is noted that a large number of authors have argued that macro adjustment should precede microeconomic deregulation, including trade liberalization. In this section the broad experience of the Latin American reformers is also discussed. It is argued that, contrary to what has become the conventional wisdom, in most

2 What is a "reasonable" level for inflation was, and continues to be, a matter of some controversy. 
Latin nations trade liberalization either preceded stabilization, or was undertaken at the same time as macroeconomic adjustment. In section III the stabilization programs implemented in a number of Latin American countries are analyzed, and the fiscal consequences of the chosen sequencing are evaluated. Section IV deals with the evolution of savings and investment during the adjustment programs, while section $V$ concentrates on real exchange rate behavior and trade reform. Finally, section VI contains the conclusions.

\section{The Sequencing of Reform: Policy Issues and Overview of the Latin American Experience.}

\section{II.1 Some Analytics on the Sequencing of Reform}

During the early phases of the crisis, the question of the sequencing between macroeconomic stabilization and structural reform - especially trade reform - became an important policy issue in Latin America. Analysts asked whether fiscal reform should precede structural reform, or whether both types of policies should be implemented simultaneously. By the late 1980 most analysts began to agree that in countries with serious macroeconomic imbalances the most appropriate sequencing required early and decisive action on the macroeconomic front, including solving the "debt-overhang" problem. " It was argued that the reason for this was that the uncertainty associated with very high inflation, including high relative price variability, would reduce the effectiveness of market-oriented structural reforms. In particular, this high degree of uncertainty would result in low investment and, in some cases, could even direct investment towards the "wrong" sectors.

A second argument for the "stabilization first" sequencing refers to the contribution of foreign trade taxes to public revenues. It has been argued that if the public finances have not been brought under control, the reduction of import tariffs would make things worse by increasing the fiscal deficit. This argument is considered to be particularly valid for low income countries, that rely very heavily on taxes on intemational trade.

3 See Edwards (1992a) for an account of the sequencing debates. For early discussions see Edwards (1984) and Fischer (1986). 
But perhaps the most important argument surrounding the sequencing debate is related to the behavior of the real exchange rate during trade reforms, on the one hand, and stabilization programs, on the other. The importance placed by liberalization strategists on the reduction of the anti-export bias has resulted in a significant emphasis on the role of exchange rate policy during a trade reform effort. A number of authors have argued that a large devaluation should constitute the first step in a trade reform process. Bhagwati (1978) and Krueger (1978) have pointed out that in the presence of quotas and import licenses a (real) exchange rate depreciation will reduce the rents received by importers, shifting relative prices in favor of export-oriented activities and, thus, reducing the extent of the anti-export bias. ${ }^{4}$

The problem, however, is that under a set of (very) plausible conditions macroeconomic stabilization programs will tend to result in an appreciation of the real exchange rate (McKinnon, 1982; Edwards, 1984; Harberger, 1985)..$^{5}$ The difficulty with this is that an appreciation of the real exchange rate will send the "wrong" signal to the real sector, frustrating the reallocation of resources called for by the trade reform. The effects of this real exchange rate appreciation will be particularly serious if, as argued by McKinnon (1982) and Edwards (1984), the transitional period is characterized by a combination of a fixed nominal exchange rate - an exchange rate anchor -, and "abnormally" high capital inflows. This suggests that the simultaneous implementation of trade reforms and major stabilization efforts can be problematic.

More recent discussions on the sequencing of reform have expanded the analysis, and have included other markets. An increasing number of authors has argued that the reform of the labor market--and in particular the removal of distortions that discourage labor mobility-should precede the trade reform, as well as the relaxation of capital controls. As is argued in Edwards (1992), it is even possible that the liberalization of trade in the

${ }^{4}$ See Krueger $(1978,1981)$ and Michaely et al. (1991).

${ }^{5}$ This would be the case if the opening of the capital account is done in the context of an overall liberalization program, where the country becomes attractive for foreign investors and speculators. 
presence of highly distorted labor markets will be counterproductive, generating overall welfare losses in the country in question. Interestingly enough, the discussions on the sequencing of reform have only addressed in detail the order in which the liberalization of various "real" sectors in society should proceed. For instance only a few studies, such as Krueger (1981) and Edwards (1984), have dealt with the order of reform of agriculture, industry, government (privatization), financial services, and education. The key question here, is the extent to which independent reforms will bear all their potential fruits, or whether the existence of synergism implies that in a broad based liberalization process the reforms in different sectors reinforce each other. ${ }^{6}$

Maintaining a depreciated and competitive real exchange rate during a trade liberalization process is also important in order to avoid an explosion in imports growth and a balance of payments crisis. Under most circumstances a reduction in the extent of protection will tend to generate a rapid and immediate surge in imports. On the other hand, the expansion of exports usually takes some time. Consequently, there is a danger that a trade liberalization reform will generate a large trade balance disequilibrium in the short run. This, however, will not happen if there is a depreciated real exchange rate that encourages exports and helps maintain imports in check.

Many countries have historically failed to sustain a depreciated real exchange rate during the transition. In the conclusions to the massive World Bank project on trade reform, Michaely et al. (1991) succinctly summarize the key role of the real exchange rate in determining the success of liberalization programs: "The long term performance of the real exchange rate clearly differentiates "liberalizers" from "non-liberalizers" (p. 119). Edwards (1989) used data on 39 exchange rate crises and found that in almost every case, real exchange rate overvaluation ended up drastic increases in the degree of protectionism.

A limitation of the "stabilization first" view discussed above is that it does not distinguish between different degrees of macroeconomic disequilibria at the time the reforms

'Of course, this discussion is related to second best analysis of policy measures. See Edwards (1992b) for a formal multisector model to analyze the welfare consequences of alternative reform packages. 
are initiated. While the relative price variability and real exchange appreciation arguments are eminently plausible for very high inflationary cases, they are unlikely to be too important in countries that start from moderate inflation. For example, Krueger (1981) has argued that the Asian and Middle Eastern experiences suggest that there is very little connection between the determinants of inflation and the orientation of the trade regime. Along similar lines, Edwards (1992) has argued that in countries with moderate rates of inflation trade liberalization and macro stabilization will tend to reinforce themselves. In particular, the reduction of import tariffs and the exposure of the domestic industry to foreign competition will tend to introduce "price discipline". Moreover, the increase in productivity growth usually associated with trade reforms will tend to offset (mild) real exchange rate appreciations that take place during the stabilization effort. A second limitation of the "stabilization first" view is that it tends to ignore the political economy of reform. Two points are in order regarding this issue. First, when embarked in a major transformation process, reform-prone policy makers tend to take advantage to whatever opportunity they have. Second, in many cases it is easier to attack the protectionist lobby - which is fairly well defined and concentrated in specific industries -, than dealing with the interest groups that lead to fiscal imbalances and inflation.

In spite of these limitations the "stabilization first" approach has become the dominant view among policy analysts, including the staff of the multilateral financial institutions such as the World Bank and the International Monetary Fund. However, as is documented in this paper almost every country in Latin America ignored this piece of advice, and either embarked on trade reform first, or implemented trade liberalization and stabilization policies simultaneously.

\section{2 An Overview of the Latin American Reforms}

Although there are still some important-and often deep-differences of opinion among Latin American leaders, we find that the region is today enjoying a degree of agreement on basic economic policy never seen before in the post-World War II period. It is possible to identify four general areas of convergence: First, there is wide recognition of the need to generate macroeconomic stability, through the control of public sector deficits. This has been recently articulated by a broad group of political leaders from very different 
political persuasions in the following way:" "Government spending must be kept in line with tax revenues and inflation must be controlled. Anti-poverty initiatives are invariably undermined by high inflation ..." The second broad element of the emerging consensus refers to the importance of opening the external sector to foreign competition. This includes a growing feeling that regional economic integration, within the context of liberalized trade with the rest of the world, should play a key role in the region's future. For example, in a clear revision of its historical position CEPAL (1992a, p.21) has recently expressed that "[i]n the long term an internationally competitive orientation...promises to be more efficient and equitable, since...additional exports are usually more labor-intensive than...import substitution".8

The third component of the new consensus refers to the recognition of the state with a greatly reduced role as a producer. The state has to provide modern supervision to some key markets-including the financial market-and make sure that the appropriate political institutions conducive to true and lasting modemization, are developed". From a policy point of view this indicates the convenience of broad privatization and deregulation programs.

In order to provide a panoramic view on how much progress has been made to date in the reforms, Table 1 contains a brief summary on five areas--fiscal adjustment, trade liberalization, financial market reform, labor market deregulation and privatization-for a large group of Latin American countries in the region. A very important feature of this table is that it clearly indicates that, contrary to conventional wisdom, trade reforms have proceeded either in tandem, or ahead of, political stabilization. Moreover, not a single country in the region has waited for stabilization to be "completed" - in the sense of inflation reaching, say, a one digit level --, before drastically slashing trade barriers.

7 See Interamerican Dialogue (1992). This group includes leaders as diverse as Luis Inacio "Lula" da Silva from Brazil and Mario Varga Llosa from Peru.

8 Of course, the agreement is more clear with respect to broad topics than detailed policy. For example, CEPAL (1992b) suggests subsidizing R\&D in certain sectors, a position that many mainstream observers would consider conducive to serious distortions. 


\title{
Table 1 - GENERAL OVERVIEW OF STRUCTURAL REFORMS IN LATIN AMERICA
}

\author{
Country \\ Fiscal Reform \\ Trade Reform
}

$\begin{array}{ll}\text { Argentina } & \text { Reform in 1990; Improvement } \\ \text { in tax administintion; tax } \\ \text { simplification implemented; } \\ \text { expendirures somewhat under } \\ \text { control }\end{array}$

Significant since 1990; export taxe eliminatod; very limited QRs; tariffs roduced to 0-22\% range

Bolivia

Major, 1985 tax structure greatly simplifiod; improved tax administration

Significant in 1985; limitad use of QRs; import tariffs reduced to S-15\% range

Brazil No action

Timid; tariffs reduced gradually; all NTBs removed in 1990

Chile Tax reform, 1975; balenced budge; tax rates increased. 1980 tax hws to be changed in 1993

Colombia

Fiscal adjustment initiated 1985-86; two tax reforms in 1991 and 1992

Major in 1975-79; QRs eliminated, uniform impor tariffs $11 \%$

Greally accelerated in 1991; average tariff reducod from $83 \%$ in 1985 to $7 \%$ in 1992

Costa Rica

Reform undertaken in 1987; tax simplification underway; tax administration reformed in 1992; expenditures control weak

Started in 1986; average tariff reduced to 20\%; come reduction in QRs coverage; export subsidies being phased out

Eoundor

No significant adjustment es of 1992

Very timid; 5-25\% tariff range announced 1992; tariff on motor-vehicles $50 \%$

El Salvador

Tax reform in progress since 1989; weak tax edministration; expenditures control very fragile

Significant since 1989; all non-tariff berriers eliminatod; turiff reduced to 5-20\% range 


\section{Table 1 - Continued}

\begin{tabular}{|c|c|c|c|}
\hline Country & Financial Market Reform & Labor Market & Privatization \\
\hline Argentins & $\begin{array}{l}\text { Free currency convertibility; } \\
\text { provincial banks not yet } \\
\text { privatizad; reserve } \\
\text { requirements still high }\end{array}$ & $\begin{array}{l}\text { No major action; rocial } \\
\text { socurity weak spot }\end{array}$ & $\begin{array}{l}\text { Asgressively since } 1991 \text {; } \\
140 \text { busineas units } \\
\text { already sold }\end{array}$ \\
\hline Bolivia & $\begin{array}{l}\text { Some action taken; Stato } \\
\text { owned banks still weak; } \\
\text { supervisory framework weak }\end{array}$ & Some distortions still remsin & Started in 1992 \\
\hline Brazil & Liale action & No reform; highly distorted & $\begin{array}{l}\text { Important steps taken; } \\
\text { process slowed in } 1993\end{array}$ \\
\hline Chile & $\begin{array}{l}\text { Major in 1975-79; interest } \\
\text { rates deregulated; no credis } \\
\text { sllocation; capital account } \\
\text { semi-open }\end{array}$ & $\begin{array}{l}\text { Major reforms in 1979; } \\
\text { Labor laws reformed in } 1990\end{array}$ & $\begin{array}{l}\text { Major; all but } 50 \text { SOEs } \\
\text { sold }\end{array}$ \\
\hline Colombis & $\begin{array}{l}\text { Interest rates deregulated; } \\
\text { credit allocation mainlaisod; } \\
\text { barriers to entry }\end{array}$ & $\begin{array}{l}\text { Labor reform in 1990; some } \\
\text { distortions remain }\end{array}$ & $\begin{array}{l}\text { Small number of SOEs; } \\
\text { no significant action }\end{array}$ \\
\hline Costa Rica & $\begin{array}{l}\text { Limited; interest rates frood } \\
1990 \text {; some credit } \\
\text { allocation still remains; } \\
\text { state banks have monopoly } \\
\text { of demand of short term } \\
\text { deposits }\end{array}$ & $\begin{array}{l}\text { No major action; some } \\
\text { rationalizstion of minimum } \\
\text { wage legislation }\end{array}$ & Very linitod progress \\
\hline
\end{tabular}

Ecuador

First stops in 1993

No action

Process to start in 1993

El Salvador Major; bank privatization

None well underway; froe interest rates; reduced credit allocation 
Table 1 - continued

$\begin{array}{lll}\text { Country Fiscal Reform } & \text { Trade Reform }\end{array}$

\begin{tabular}{|c|c|c|}
\hline Guaternala & $\begin{array}{l}\text { Tax reform 1992; VAT } \\
\text { covernge broadened; } \\
\text { exemptions eliminated; tax } \\
\text { administration reform in } \\
\text { progress }\end{array}$ & $\begin{array}{l}\text { In progress since 1987; tariff } \\
\text { range reduced to 5-30\%, } \\
\text { programmed to 5-20\%; NTBs } \\
\text { coverage reduced }\end{array}$ \\
\hline Guyana & $\begin{array}{l}\text { Major tax reform; partial } \\
\text { fiscal adjustment; primary } \\
\text { current account surplus of } \\
\text { 32\% of GDP in 1992; } \\
\text { initiation of tex and customs } \\
\text { administration reform }\end{array}$ & $\begin{array}{l}\text { Exchange rate liberalization in } \\
\text { 1991; adoption of CARICOM } \\
\text { revised CET in 1991, with a } \\
\text { range of 0-45\%; groement to } \\
\text { reduce tariff to O-20\% by } \\
\text { 1997; drastic roduction in } \\
\text { trade licensing requirements; } \\
\text { no other non-tariff barriers }\end{array}$ \\
\hline Honduras & $\begin{array}{l}\text { Partial fiscal \&djustment } 1990 \\
92 \text {; tex administration still } \\
\text { weak; public section deficit } \\
\text { 3.5\% of GDP }\end{array}$ & $\begin{array}{l}\text { Reduced lariff range since } \\
\text { 1992, 5-20\%; exchange rate } \\
\text { unification in 1990; NIBs } \\
\text { eliminated in 1992 }\end{array}$ \\
\hline Jamaica & $\begin{array}{l}\text { PSBR roughly zero for last } \\
\text { FY; continuing fiscal } \\
\text { adjustment to meet IMF } \\
\text { targets for surplus this FY; } \\
\text { tax administration weak but } \\
\text { major reform is beginning }\end{array}$ & $\begin{array}{l}\text { Tariffs roduced } 4 / 1 / 93 \text { to } 5- \\
30 \% \text { ( } 40 \% \text { for agricultural } \\
\text { products) range as part of } \\
\text { CARICOM agrecment, which } \\
\text { will bring all rates to } 5-20 \% \\
\text { range by } 1 / 1 / 98\end{array}$ \\
\hline Mexico & $\begin{array}{l}\text { Fiscal adjustment since } 1985 \text {; } \\
\text { tax reforms; improved tax } \\
\text { administration }\end{array}$ & $\begin{array}{l}\text { Major since 1985: NTB } \\
\text { coverage reduced from } 90 \text { to } \\
\text { 17\%; tariff range } 0-20 \% \text {; } \\
\text { tarif average } 13 \%\end{array}$ \\
\hline Nicaragua & $\begin{array}{l}\text { Major, 1991; weak } \\
\text { edministration; currently } \\
\text { balanced budget (including } \\
\text { grants) }\end{array}$ & $\begin{array}{l}\text { Significant 1992; trade } \\
\text { privatized; tariffs roduced to } \\
\text { 10-40\% range; greatly } \\
\text { reduced QRs }\end{array}$ \\
\hline Paraguay & $\begin{array}{l}\text { Tax reform in progress; poor } \\
\text { tax administration; } \\
\text { expenditures under control }\end{array}$ & $\begin{array}{l}\text { Recently undertaken; major } \\
\text { tariff roduction; maximum } \\
\text { tariff }\end{array}$ \\
\hline
\end{tabular}


Table 1 - continued

Country Financial Markat Reform Labor Markat Privatization

$\begin{array}{ll}\text { Guatemala } & \begin{array}{l}\text { Interest rates freod in 1989; } \\ \text { credit allocation eliminaled; } \\ \text { capital account partinlly } \\ \text { open }\end{array} \\ \text { Guyana } & \begin{array}{l}\text { Introduction of market- } \\ \text { determined interest rates in } \\ \text { 1991; weak supervision; } \\ \text { domination by stato-owned } \\ \text { Gnancial institutions }\end{array}\end{array}$

Honduras Interest rates freod in 1992 some credit allocation remains; supervisory problems remain

Jamaics

Interest rates free; reserve requirements to be brought down; open to foreign banks

Mexico

Nicaragua

Private banks allowod; free interest rates; state banks still dominate

Paraguay

Contemplated; fairly open capital account
No significant action

No significant action

Initiation of comprehensive privatization programs; 14 public enterprises divested; 20 companies still statc-awnod

No action

No action

No action

Major privatization program underway, supported by forthcoming PSDAL

Minor

Major: 100 SOEs already rold; 37 SOEs to be privalized in 1993

No action

Significant, but still very serious property problems

No action

Limited action, constitutional problems encounterad 
Table 1 - continued

Country

Fiscal Reform

Trade Reform

Petr

No tax reform; improved tax administration; substantial control of expenditures

Significant, 1990; limited QRs tariff renge 5-15\%

Trinidad and Tobago

Fiscal adjustment 1989 present; VAT (15\%) introduced 1989; public sector deficit $9.5 \%$ of GDP in 1986 , $1 \%$ in 1991

Last QRs on manufacturod imports eliminated in 1992; CARICOM CET adoptod, tariff range to be nasrowed gradually to $5-20 \%$ by 1988

Uruguay

Tex reform in progress; social Mild reform; reference prices sccurity is major fiscal burden important; $Q R s$ abolished edjustment since 1990

Significant; QRs coverage roducod 1991; tariff range roduced to 0-25\% 
Table $1 \cdot$ continued

Country Finencial Market Reform Labor Market Privatization

Peru

In progress; state banks atill very important; froe interest rates; some credir allocation; capital account open

Trinidad and

Tobago

\section{Uruguay}

Venezuela
Financial soctor relatively undistortod; major divestment of 2 ststo-ownod banks in 1991-1992; exchange rage floated; restrictions on forcign exchange transactions eliminated

Major reform completed; two bankorupt banks; capital account already open

Little action taken
Deregulation contemplated but no yat implemented

No significant action; youth training program in operation

No reform; indexed public sector wages

No action
Major action since 1992; 30\% of SOEs already privatized (including Hierro Peru Iron company)

Major divestment program underway, 23 SOE largeted for divestment: Fertrin and T\&T Ura Company sold April 1993

Very slow; Plebiscite in November 1992 against massive privatization policy

Some action; 77 SOEs ilready sold 
Table 2 contains more detailed information on the extent of trade reform in Latin America. The pioneer in this area was Chile, which between 1975 and 1979 unilaterally eliminated QRs and reduced import tariffs to a uniform level of $10 \%$. After a brief interlude with higher tariffs (at the uniform level of 35\%) Chile currently has a uniform tariff of $11 \%$ and no licenses or other forms of quantitative controls. Uruguay implemented a reform in 1978, and after a brief reversal, push forward once again in 1986. Bolivia and Mexico embarked on their reforms in 1985-86, followed by a series of countries in the late 1980s. The members of the Caribbean Community (CARICOM) intensified trade liberalization reforms in the late 1980s and early 1990s. At the current time a number of nations, including Brazil, are proceeding steadily with scheduled rounds of tariff reduction and the dismantling of quantitative restrictions. However, it is still unclear whether all these reforms will be sustained, becoming a permanent feature of the Latin economies, or whether some of them will be reversed. Recent (October 1992) developments in Argentina indeed suggest that in some countries higher tariffs may be implemented, once again, in the near future. Moreover, the possible rejection of NAFTA and the failure to implement GATT's Uruguay Round may produce sentiments of unfair treatment in Latin America, prompting some back tracking in the liberalization process.

The Latin American and Caribbean trade reforms have been characterized by four basic elements: (1) The reduction of the coverage of non-tariff barriers, including quotas and prohibitions; (2) The reduction of the average level of import tariffs; (3) The reduction of the degree of dispersion of the tariff structure; (4) The reduction or elimination of export taxes. These measures were initially supported, in most countries, by exchange rate policies aimed at maintaining a competitive real exchange rate.

With respect to macroeconomic stabilization, the programs implemented in Latin America during the late 1980 s dealt with four basic and interrelated issues. First, programs aimed at reducing the burden of the foreign debt were designed in most countries. This was required to break the vicious circle generated by the debt overhang problem, and to help smooth the transition towards market-oriented systems. In order to do this a number of channels were used, including debt-equity swaps, debt-conversion schemes, debt restructuring and, after the introduction of the Brady Plan in 1989, voluntary debt reduction agreements 


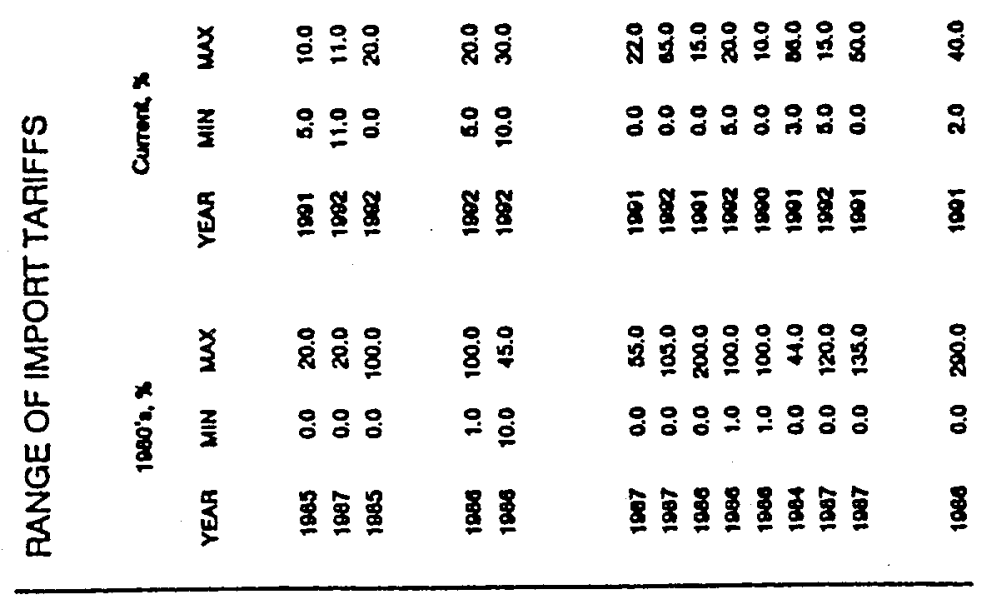

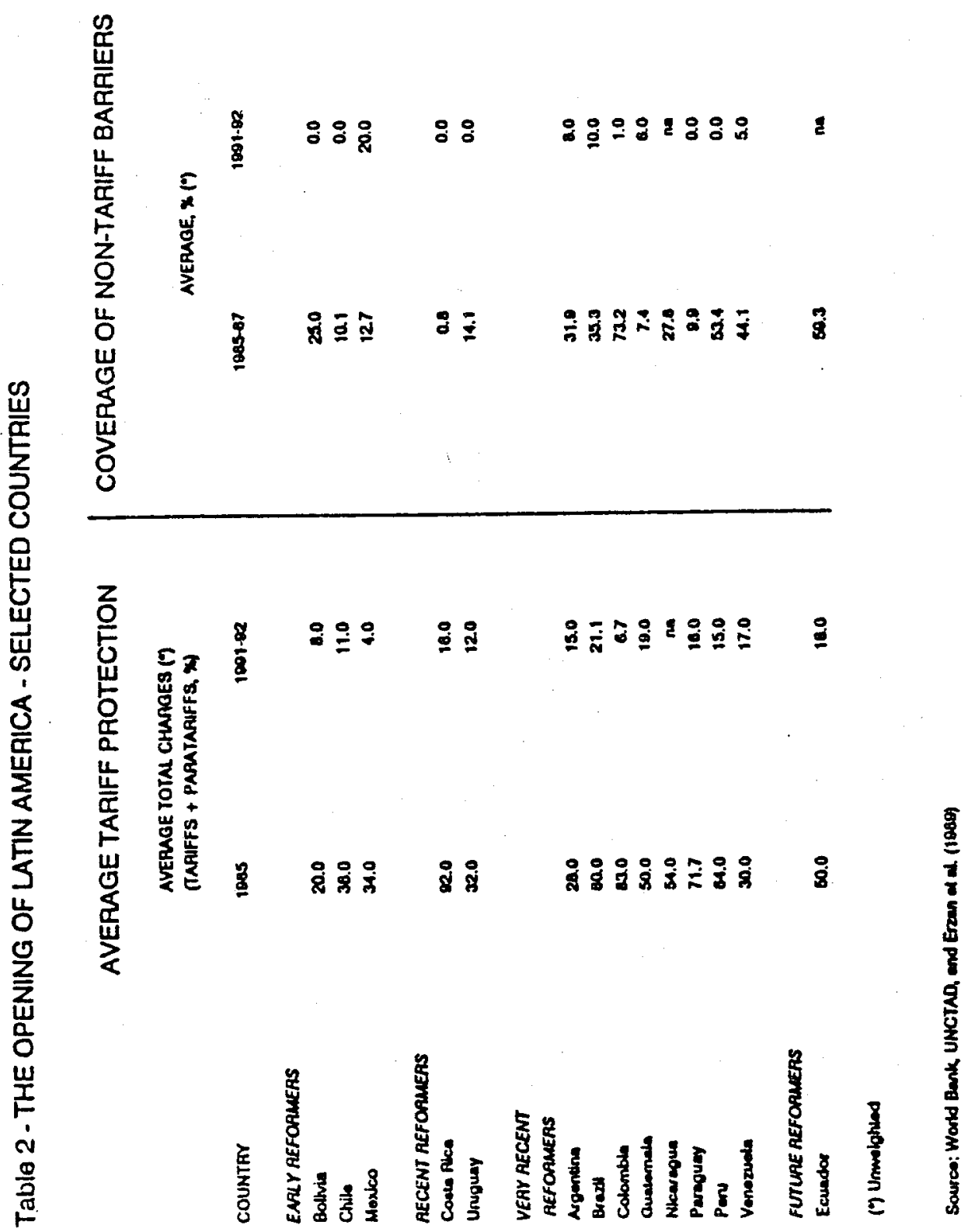


with commercial banks. Second, fiscal adjustment programs aimed at reducing the public sector deficit were implemented in most countries. This was done through a number of initiatives, including tax reforms, expenditure cuts and, in a number of countries, the sale of state owned enterprises to both domestic and foreign parties. In many countries privatizations were linked to debt-equity swaps, where foreigners exchanged outstanding debt for stakes in state owned enterprises. Third, the macroeconomic adjustment packages required the implementation of consistent domestic credit policies that, at the same time, relieved the pressures on aggregate demand and avoided crowding out the private sector. And, fourth, exchange rate policies consistent with the anti-inflationary effort had to be designed. As will be seen in this paper, this has been particularly difficult since, under most circumstances, there is a trade-off between using the exchange rate to guide inflation downward-the use of the exchange rate as a "nominal anchor"-and using it to maintain a competitive real exchange rate position in the country. In addition to tackling these four problems, the Latin American countries had to build credibility for their programs. This was required both to achieve macroeconomic equilibrium at a reduced cost, and to ensure that the reforms would be sustained through time.

In most countries - Brazil being the main exception - these stabilization programs have resulted in slowly declining rates of inflation (Table 3). Only recently, however, are some countries achieving a one digit level. In the section that follows I discuss the way in which the sequencing chosen in most Latin American countries - trade liberalization first impacted on the trade sector.

\section{III.- Macroeconomic Stabilization in Latin America}

III.1 Fiscal Imbalances and Macro Disequilibrium

Fiscal imbalances have traditionally been at the heart of Latin America's macroeconomic disequilibrium. Governments inability, or unwillingness, to raise sufficient tax revenues to cover expenditures have forced them to rely on money creation, or seignorage, to finance the public sector deficit.' Additionally, in many countries the tax

9 In some countries govemments covered part of their deficit by floating domestic debt. However, given the underdeveloped nature of the region's capital markets, this was a limited 


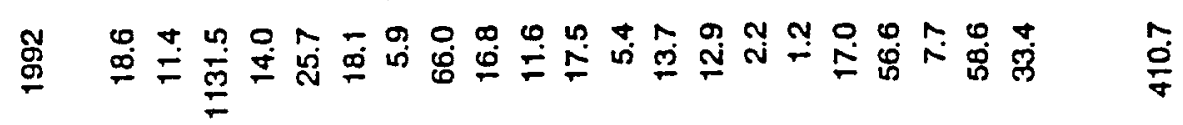

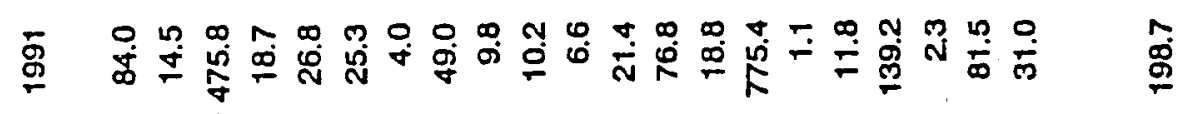

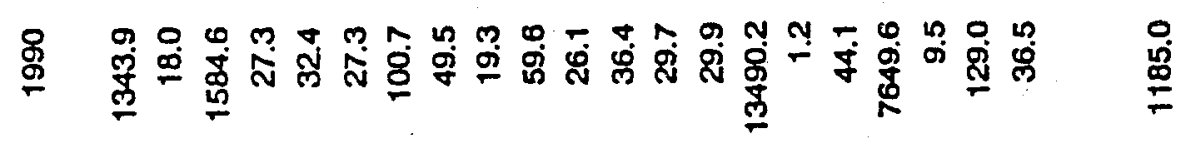

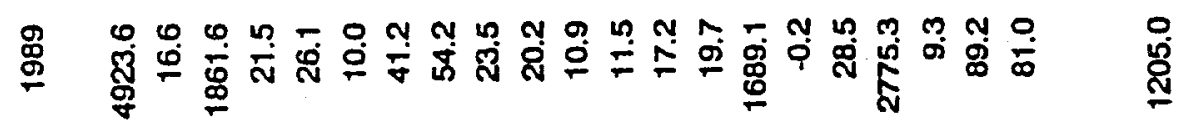

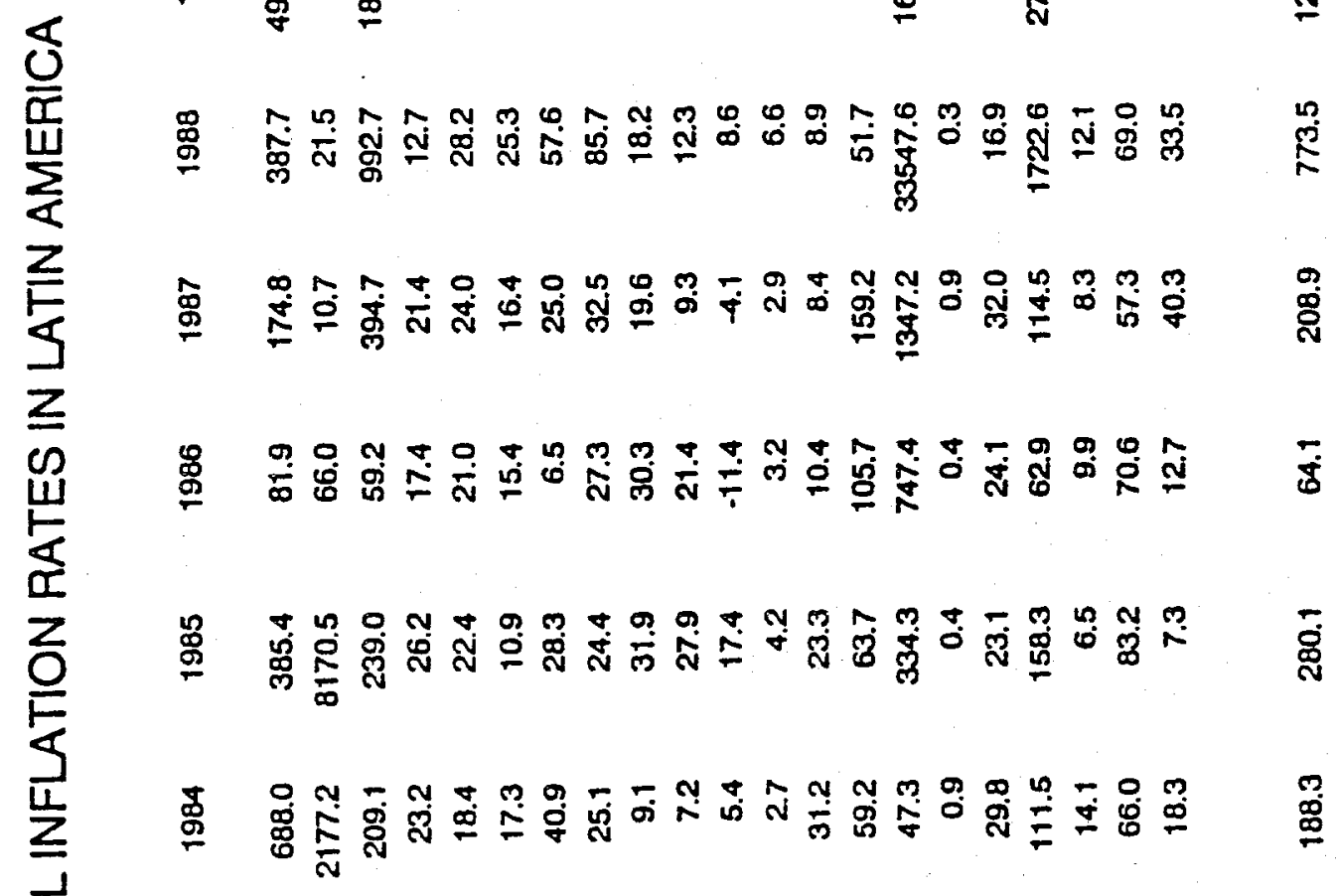

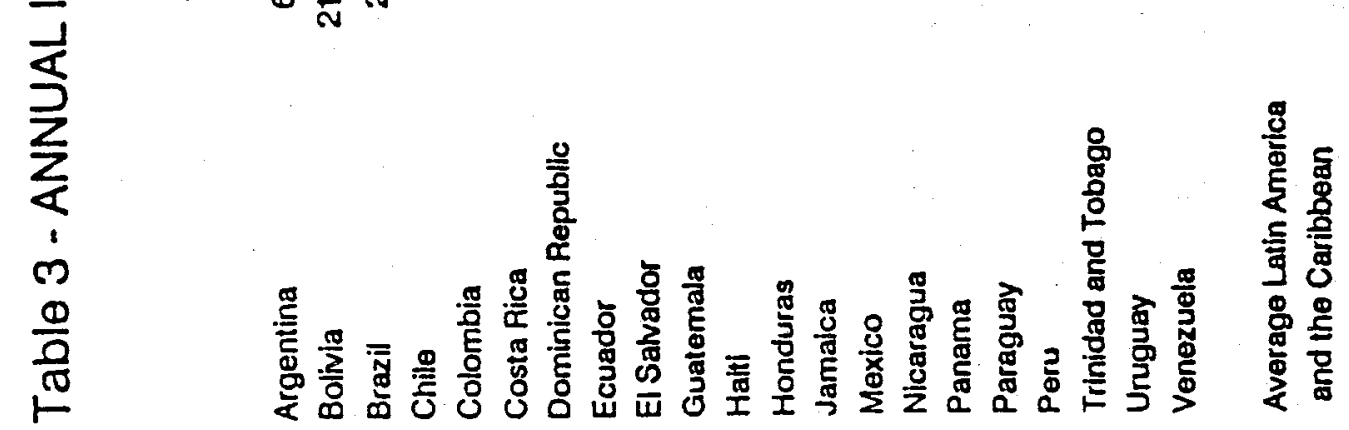


system has traditionally relied on an array of inefficient taxes. In particular, a large number of countries have historically relied on indirect taxes and taxes on international trade

The reliance on money creation to finance public expenditures affects the macroeconomy in several ways. First, it generates inflationary pressures. The magnitude of these forces will depend on a number of factors, including the size of the public deficit, the rate of growth of the economy, and the elasticities of the demand for money. ${ }^{10}$ Second, under predetermined nominal exchange rates, the creation of domestic money at a rate that exceeds the growth in money demand will generate serious balance of payments difficulties, and real exchange rate overvaluation. Under these circumstances, an increase in the rate of monetary growth will be translated into higher demand for tradable goods, nontradable goods, and financial assets. The increases in the demand for tradables will generate a trade deficit, rapid increases in foreign borrowing, and a loss in international reserves. The higher. demand for nontradables, on the other hand, will result in a higher price for nontradables and a real exchange rate overvaluation. This situation will eventually become unsustainable, and generate a major balance of payments crisis whose solution will require a substantial nominal devaluation and austere policies.

A natural implication of public finance-based approaches to inflation is that, for given values of some key parameters, there will be an optimal level of seignorage, or inflation tax. This will depend on the welfare costs of inflation and of alternative sources of public sector revenues, and on the costs of raising regular taxes."

option. Clearly, a vicious circle developed, where the lack of sophisticated capital markets precluded using domestic debt as a source of financing and, in turn, inflation discouraged the growth of the financial sector. See World Bank (1993), Chapter 7 for a discussion on capital markets reform.

10 In the absence of growth the inflationary pressures associated with a debt/GDP ratio of $\delta$ will be equal to $\delta / \lambda$, where $\lambda$ is the ratio of base money to GDP. See Edwards (1988a) and Dombusch and Fischer (1993).

11 For classical analyses on the optimal inflation tax, and the revenue-maximizing inflation tax see Friedman (1971) and Bailey (1956). See Edwards and Tabellini (1991) for an empirical discussion on the intertemporal implications of the optimal inflation tax theories. 
In recent analyses a growing number of authors have emphasized the political economy dimensions of the problem. ${ }^{12}$ These authors have argued that the reliance on seignorage to finance the public deficit is highly influenced by the political conditions of the country. Very often politicians behave strategically, trying to constrain their opponents' policy options. This type of behavior tends to result in political gridlock, inefficient tax systems and, thus, in inflation. In some circumstances political polarization can be so intense that the government in question will be forced to operate on the "wrong side" of the seignorage Laffer curve. ${ }^{13}$

An important feature of the political economy approach to inflation is that macroeconomic disequilibrium, including the use of seignorage to finance public expenditures, is directly related to the government inability to credibly precommit itself to a certain line of action. Politically motivated governments face large incentives to renege on their promises, and to run public deficits above what they have promised. The simultaneous implementation of fiscal corrections and institutional reforms allows the authorities to precommit themselves to certain courses of actions, reducing potential macroeconomic imbalances.

The fundamental policy implication of the preceding discussion is the crucial role of a credible reduction (or elimination) of the public sector deficit in stabilization programs. Although in many successful anti-inflationary episodes fiscal action has been supplemented by other measures--including income policies--the correction of the public sector finances has invariably been the most important component of those programs.

As pointed out above, within the context of a broad reform program, there is the possibility of severe conflicts between the objective of reducing public deficits and the objective of increasing efficiency. In particular, under some circumstances, trade liberalization will result in a higher fiscal deficit. This would be the case, for example if

${ }^{12}$ See, for example, Alesina (1988) and Alesina and Drazen (1991).

${ }^{13}$ See Bruno (1992), Edwards and Tabellini (1991) and Dornbusch and Fischer (1993). 
tariff reduction is the main vehicle for opening up the economy. ${ }^{14}$ However, if as is often the case in developing nations, the most important element of trade reform is the elimination of QRs - or their replacement by tariffs - there is no need for the trade liberalization policies to impact negatively on the public sector deficit. Which of these two effects will dominate is, ultimately, an empirical issue.

\section{2 Fiscal Austerity in the Late 1980s}

During the latter part of the 1980s and early 1990s, most Latin American countries made efforts to reduce their public sector imbalances, as a way to restore macroeconomic equilibrium and foster economic growth. These efforts were based on a combination of revenue increasing policies-including tax reforms, privatization of public firms, and improved tax administration-and expenditure cuts. Tables 4 through 7 provide a broad summary of the magnitude of the adjustment programs in a selected group of countries.

Table 4 deals with the bottom line, and contains data on the evolution of the consolidated public sector deficit as a percentage of GDP, for eleven countries. An advantage of these data is that they refer to the public sector-including government-owned enterprises, provinces and municipalities-and not to the narrower concept of central government. For years many Latin countries exhibited relatively balanced central government accounts and very high deficits in the public sector ledgers. As can be seen, in most cases there has been a marked improvement in public finances; with the exception of Costa Rica and Brazil in 1991, every country in the table has drastically reduced its public sector deficit relative to the mid-1980s.

Mexico and Nicaragua are two startling cases, where substantial-and in the case of Nicaragua, truly gigantic-deficits have been transformed into large surpluses. Nicaragua's adjustment after 1990 was part of the Chamorro administration's successful battle against hyperinflation. The control of the public finances, coupled with other measures that included the fixing of the nominal exchange rate and the reprivatization of a number of enterprises, helped reduce the rate of inflation from $18,000 \%$ in 1990 , to a $3.7 \%$ in 1992 . In Mexico, the turnaround in the fiscal deficit has been the central component of the stabilization

\footnotetext{
${ }^{14}$ This assumes that the existing (average) tariff is below the maximum revenue tariff.
} 


\section{Table 4 - PUBLIC SECTOR BALANCE AS PERCENTAGE OF GDP Selected Countries and Years $\left({ }^{\star}\right)$}

$\begin{array}{lrrrrrr} & 1986 & 1987 & 1988 & 1989 & 1990 & 1991 \\ \text { Argentina } & -4.1 & -6.5 & -7.0 & -21.8 & -3.3 & -1.8 \\ \text { Brazil (a) } & -3.7 & -5.7 & -4.8 & -6.9 & 1.3 & 3.0 \\ \text { Chile } & \mathrm{na} & -4.3 & -0.7 & 3.5 & 1.6 & 0.3 \\ \text { Colombia (b) } & -0.3 & -2.0 & -2.2 & -29 & -0.8 & -0.1 \\ \text { Costa Rica (b) } & \mathrm{na} & -0.3 & -0.3 & -2.8 & -29 & \mathrm{na} \\ \text { Ecuador } & -5.1 & -9.6 & -5.1 & -0.9 & 0.4 & \mathrm{na} \\ \text { Mexico } & \mathrm{na} & \mathrm{na} & \mathrm{na} & -1.6 & 1.2 & 3.5 \\ \text { Nicaragua } & \mathrm{na} & \mathrm{na} & -36.7 & -18.4 & -17.8 & 4.0 \text { (p) } \\ \text { Peru } & \mathrm{na} & \mathrm{na} & \mathrm{na} & -10.7 & -6.5 & 3.2 \\ \text { Uruguay } & -5.2 & -4.2 & -5.0 & -7.6 & 3.6 & \mathrm{na} \\ \text { Venezuela (c) } & \mathrm{na} & -5.4 & -9.3 & -1.3 & \mathrm{na} & -3.0 \text { (p) }\end{array}$

(") A positive number is a surplus; a negative number is a deficit.

(a) Operational nonfinancial deficit, including net interest payments.

(b) Data refer to nonfinancial public sector.

(c) Data refer to the so-called "Reduced Public Sector.

(p) Preliminary.

Sources: IMF, Wordd Bank, and individual country reports 
program aimed at recovering the country's historical macroeconomic stability, and achieving rates of inflation consistent with those prevailing in its (future) NAFTA partners.

Chile is another interesting case of deficit management. In the mid-1980s, and as a result of the debt crisis and the failure of a number of financial institutions, Chile developed large public sector deficits. ${ }^{\text {IS }}$ These, however, were eliminated in 1988-89 through reduced expenditures and a new tax reform. The generation of positive government savings became an important component of the government strategy to accelerate growth; by 1989 a comfortable public sector surplus had been achieved. ${ }^{16}$ The existence of this surplus allowed the new administration of President Aylwin to finance an increase in social expenditures aimed at reducing poverty and improving income distribution in the early 1990s.

Brazil and Argentina provide contrasting experiences. Between 1986 and 1988 both countries experienced significant fiscal disequilibria that were closely related to the failure of the heterodox experiments. Public sector finances deteriorated rapidly in Argentina until, in early 1989, the country suffered a complete breakdown of macroeconomic management and flirted dangerously with hyperinflation. In late 1989, the new administration of President Menem embarked on a serious stabilization program that, as discussed in greater detail below, centered its efforts on a drastic reduction of the government deficit. Brazil, on the other hand, followed a divergent path. After a brief interlude with fiscal austerity during the early years of the Collor de Mello administration, the country slipped back into increasingly large public imbalances, that have fed a voracious inflation which reached 1,195\% in 1992.

In most countries the improvement in the public sector accounts has been accomplished through a combination of higher revenues and lower expenditures. On the revenues side, most programs included: (a) tax reforms aimed at improving the efficiency and effectiveness of the tax system; (b) improvements in tax administration, including efforts

1s See chapter 7 of World Bank (1993) for a discussion of the Chilean financial crisis of the early 1980s.

16 See Fontaine (1989) for a discussion of the government's macroeconomic strategy during this period. 
to reduce evasion; (c) increases in public services prices in order to cover costs; and (d) sales of state owned enterprises.

Table 5 contains information on tax revenues for a selected group of countries. As can be seen, with the exception of Costa Rica, in every country tax revenues were higher in 1991 than in 1987-88. Table 6 presents data on the contribution of taxes on international trade to central government revenues for a group of early trade reformers. As the data show, in the majority of these cases the trade liberalization effort resulted in a substantial decline in trade taxes revenues, forcing these countries to find alternative sources of public funds. In most countries these increases in other (non trade related) revenues were achieved through a combination of improved tax administration and tax reforms. ${ }^{17}$ It is important to note, however, that while in relatively advanced and sophisticated countries it may be possible to engineer tax reforms in a somewhat short period of time, in less advanced nations - the poor Central American countries, for example - putting in place a modern tax system would take a substantial amount of time. In this case a trade reform characterized by a reduction in import tariffs will tend to negatively affect public finances. This may explain why, IMF programs in small and poor countries often do not include the reduction of import tariffs as a condition. For example, during the first year of the debt crisis (1983) only one third of the IMF high-conditionality programs required tariff liberalization (Edwards, 1989).

Table 7 deals with the evolution of public sector expenditure between 1987 and 1991 . Two interesting facts emerge from this table: first, in every country, with the exception of Venezuela, total public sector expenditures were lower in 1991 than in 1987. A comparison of the evolution of tax revenues and expenditures shows clearly that the reduction in the latter have made the greatest contribution to the attainment of fiscal equilibrium in the region. In many countries expenditures have been reduced across the board, affecting social programs. Many countries tackled this problem by trying to increase the efficiency of social programs and targeting social expenditures.

17 The detailed experiences with tax reform and improved tax administration in a group of countries are analyzed in grater detail in Edwards (1993). 


\section{Table 5 - TAX REVENUES AS PERCENTAGE OF GDP Selected Countries and Years}

$\begin{array}{lrrrrr} & 1987 & 1988 & 1989 & 1990 & 1991 \\ \text { Argentina (a) } & 17.8 & 16.2 & 14.9 & 19.1 & 20.0 \\ \text { Brazil } & 18.1 & 17.8 & 18.4 & 23.9 & 21.2 \\ \text { Colombia } & 14.9 & 14.4 & 14.4 & 14.4 & 15.8 \\ \text { Costa Rlca } & 22.4 & 22.0 & 22.7 & 22.2 & 22.2 \\ \text { Mexico } & 8.6 & 9.6 & 10.2 & 10.5 & 10.7 \\ \text { Nicaragua } & \text { na } & 20.9 & 24.6 & 16.6 & 24.0\end{array}$

(a) Includes national administration plus social security taxes.

Source: IMF, World Bank, and individual country reports 


\section{Table 6 - TAXES ON INTERNATIONAL TRADE AS PROPORTION OF TOTAL GOVERNMENT REVENUES $\left(^{*}\right)$ Selected Latin American Countries (percent)}

$\begin{array}{ll}\text { Before trade } & \text { After Trade } \\ \text { reform (a) } & \text { reform (b) }\end{array}$

$\begin{array}{lcc}\text { Bolivia } & 20.5 & 5.4 \\ \text { Chile } & 11.1 & 9.7 \\ \text { Costa Rica } & 21.1 & 19.7 \\ \text { Mexico } & 23.7 & 4.5 \\ \text { Peru } & 20.6 & 10.8 \\ \text { Venezuela } & 18.3 & 8.2\end{array}$

$\left({ }^{\star}\right)$ In all cases the reported figures refer to total taxes on trade as a percentage of the consolldated central government revenues.

(a) These data are averages for the following periods: Bolivia 1984-86, Chile 1972-74, Costa Rica 1984-86, Mexico 1984-85, Peru 1984-86, Venezuela $1984-86$.

(b) These data refer to the following periods: Bolvia 1991, Chile 1991 , Costa Rica 1991, Mexico 1990, Peru 1991, Venezuela 1991.

Source: IMF, Government Finance Statistics, 1992 
号

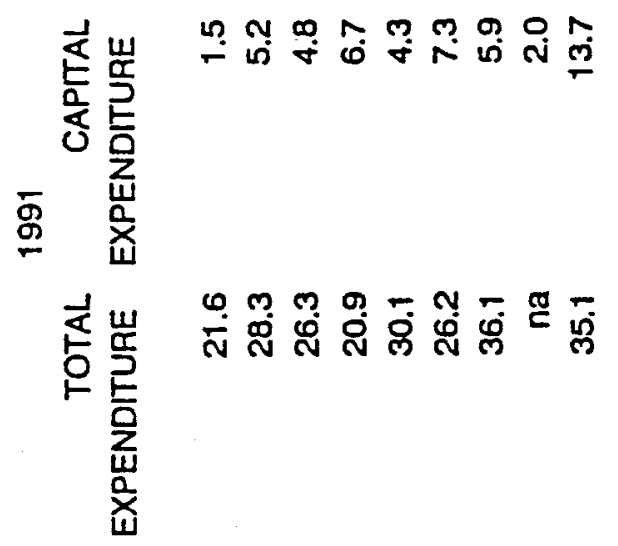

$\frac{0}{\frac{0}{2}}$

<

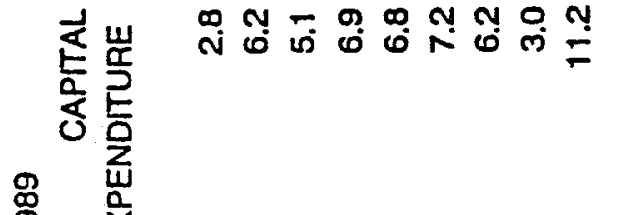

는 党 总

I昂

岁 岁.

山

崩 心

卢占至

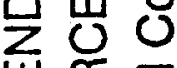

ш 중

呈㟔

站

$\frac{1}{<} \frac{\mathscr{N}}{\Phi}$

兽

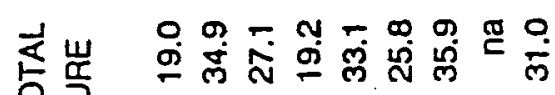

战

象

它

志崖

这岲

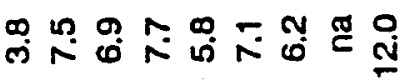

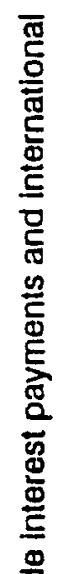

.

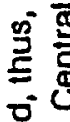

ฝู่
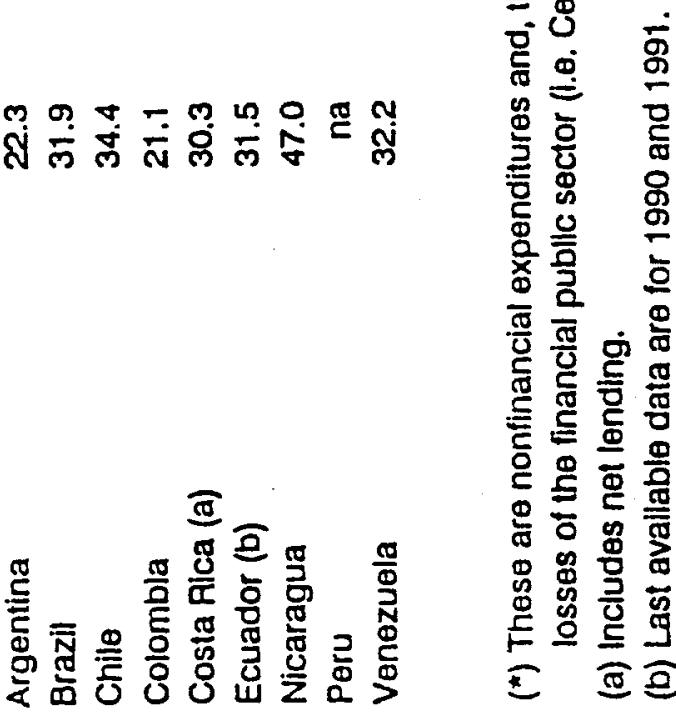

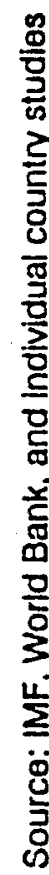


A second feature of the expenditure adjustment programs that emerges from Table 7 is that, in almost every country, capital expenditures have been reduced in a very drastic fashion. In four out of the eight countries with available data, capital expenditures were in 1991 more than $25 \%$ lower than the already depressed levels of 1987 . The nature of these cuts varied from country to country. In some cases large and inefficient government projects have been canceled or postponed; in others, however, public investment in infrastructure has been cut, generating some serious shortcomings in transportation and power provision. Also, in some countries, including Mexico, Chile and Argentina, capital expenditures that were traditionally made by the government are increasingly being handled by the private sector. For example, in Mexico allowing the private sector to charge tolls in newly constructed highways has resulted in a spurt in roads construction. However, very high tolls for using these highways have resulted in a somewhat low degree of utilization. Also, the Mexican government has actively encouraged private sector involvement in water provision and treatment, garbage collection and the generation of electrical power-all of them activities that had traditionally been reserved for government owned companies.

In many countries interest payments on public sector debt-both domestic and foreign-represent a large proportion of total public sector expenditures. In fact, when these payments are excluded, and we concentrate in the so-called primary deficit, we find that most countries have been able to achieve very substantial adjustments. Perhaps the most impressive case is that of Argentina, which in 1989 had a consolidated public sector deficit of almost $22 \%$ of GDP, and a primary deficit of only $0.4 \%$ of GDP. In that year, and as a result of a remarkable surge in inflation, interest payments on the domestic nonfinancial sector indexed debt surpassed $15 \%$ of GDP.

A large internal debt can seriously jeopardize macroeconomic stability when, as has traditionally been the case in most of Latin America, it is concentrated on short term maturity instruments. Changes in short term interest rates stemming from changing world conditions, from macro-policy measures, or, purely from "adverse" expectations, will have a huge impact on the public sector deficit. A large number of countries is recognizing this problem, and are actively trying to reduce the stock of domestic debt, as well as lengthening its maturity. Chile and Mexico are, perhaps, the most active in this area. Calvo (1988) has 
argued that in the presence of non-indexed domestic debt, a situation of self-fulfilling high inflation expectations can materialize. This line of analysis appears to be promising for understanding the Brazilian inflationary process, where a relatively low domestic debt and a primary surplus in the public sector co-exist with monthly inflation rates of 30 percent.

An interesting peculiarity of Latin America's public finances is that in many countries the financial public sector has recently been the source of sizable deficits-the so-called quasi-fiscal deficits. In most cases these deficits stem from Central Bank operations that subsidize a particular group. For example, two typical sources of quasi fiscal deficits are dual exchange rates-where the central bank buys "expensive" foreign exchange at the ongoing rate, and sells it "cheaply" to a particular user-and bail-out operations of the financial sector. In the latter case the central bank usually acquires low quality, or nonperforming assets, from a financial institution about to fail. Since this operation is financed by issuing interest paying obligations, the net effect is an operational loss for the central bank. This has been the case of Chile, for example, where since the financial crisis of 1982 83 the central bank has incurred in very large losses (see Table 8). In Argentina, on the other hand, the main cause of the quasi fiscal deficit has been the payment of (high) interest rates on commercial banks legal reserves. It is interesting to note that most trade reform programs include the unification of exchange rates, and thus eliminate one the most important sources of quasi-fiscal deficit.

\section{III.3 Credit Policy}

An important component of the Latin American stabilization programs has been the control of domestic credit, to the public sector and private sector-see Figure 1 for data on selected countries. During the early years of the adjustment (1982-87), most of the burden of credit reduction fell on the private sector. This was, in part, a consequence of the sudden cut in the availability of foreign funds to finance public expenditures. Most governments reacted by borrowing heavily from the domestic banking system, crowding out the private sector. As a consequence real interest rates increased sharply, and aggregate demand declined. However, as the adjustment proceeded, and foreign financing was partially restored through debt restructuring, interest capitalization and debt reduction, it was possible for governments to ease credit restrictions to the private sector (figure 2). 


\section{Table 8 - FINANCIAL PUBLIC SECTOR QUASI-FISCAL DEFICIT Selected Countries and Years \\ (Percentage of GDP)}

$\begin{array}{lrrrrrr} & 1986 & 1987 & 1988 & 1989 & 1990 & 1991 \\ \text { Argentina (a) } & 1.6 & 0.9 & 0.7 & 5.9 & 1.0 & 0.6 \\ \text { Chile (a) } & \text { na } & 3.9 & 3.2 & 1.8 & 2.2 & 1.9 \\ \text { Peru (b) } & \text { na } & \text { na } & \text { na } & 2.8 & 1.1 & 0.5 \\ \text { Uruguay (c) } & 3.9 & 2.8 & 3.1 & 4.0 & 4.1 & \text { na }\end{array}$
(a) Refers to Central Bank.
(b) Covers Central Bank and Banco Agrario losses.
(c) Includes Central Bank and intervened banks' operational losses.

Source: IMF, World Bank, and individual country documents 
FIGURE 1

\section{ANNUAL GROWTH RATES OF DOMESTIC CREDIT}
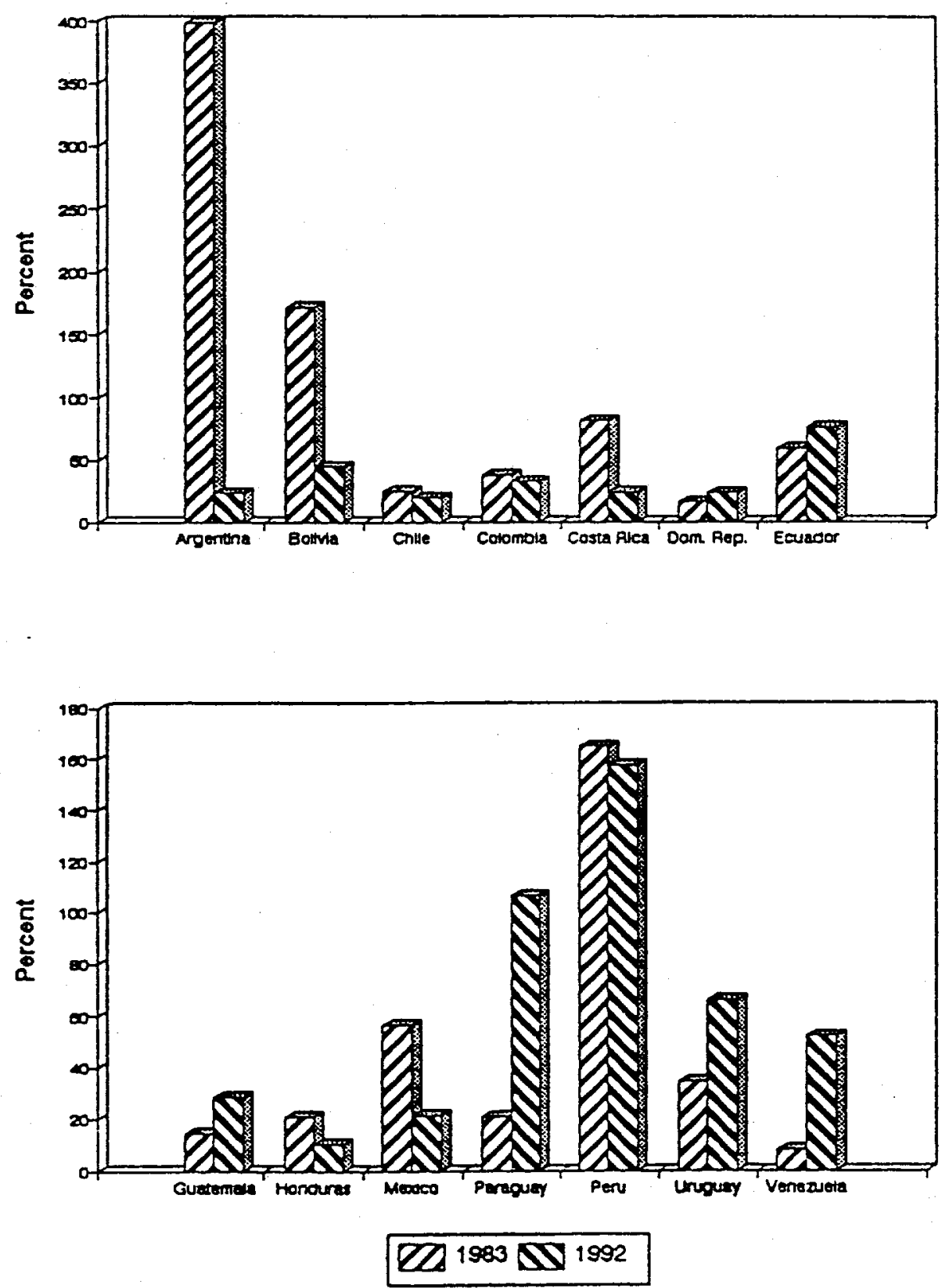

Note: Available data for Ecuador and Peru correspond to 1991.

Source: IMF, International Financial Statistics 
FIGURE 2

\section{DOMESTIC CREDIT TO THE PRIVATE SECTOR PERCENT OF TOTAL DOMESTIC CREDIT}
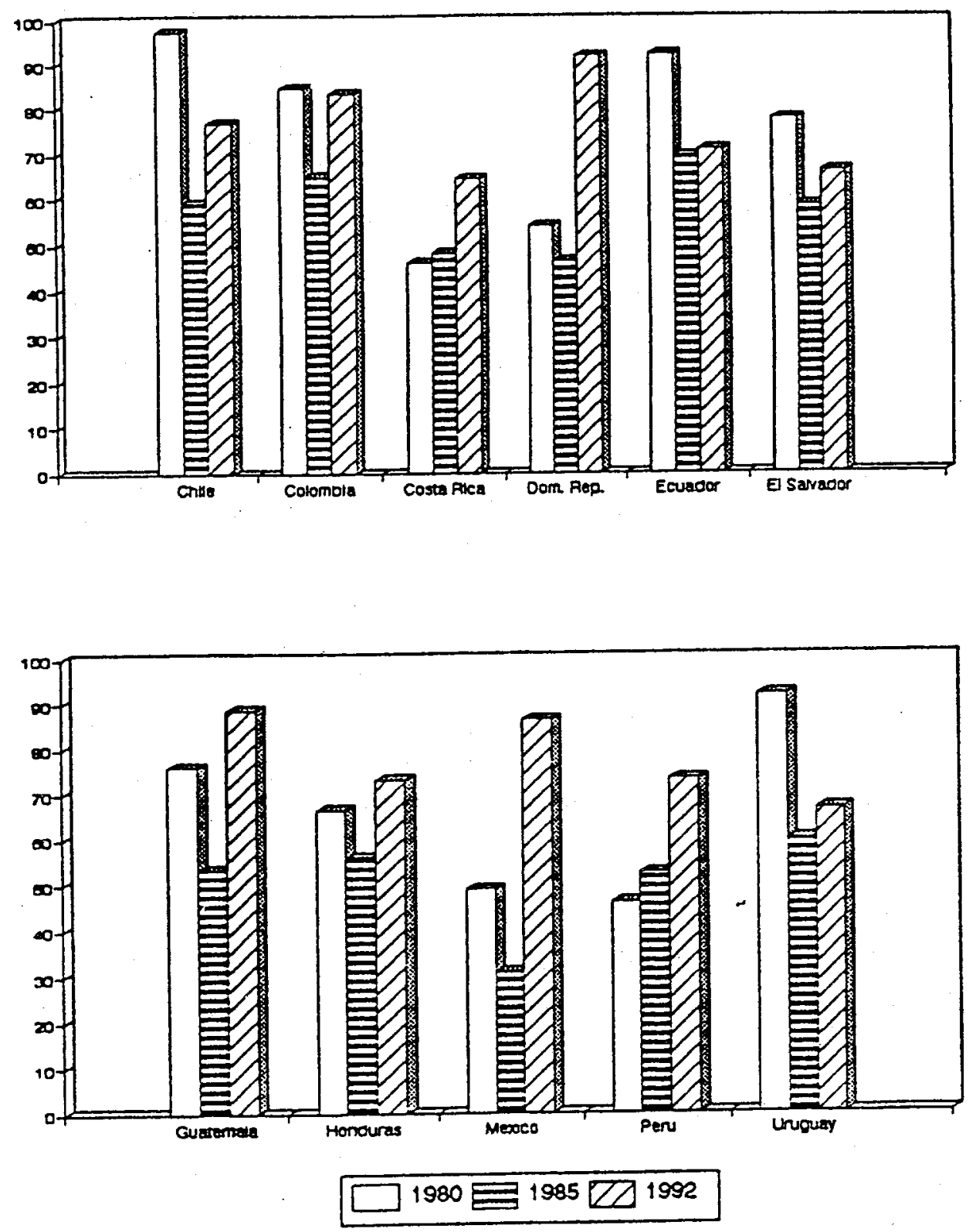

Note: Avallable data for Ecuador and Peru correspond to 1991.

Source: IMF, International Financial Statistics 
The financial deregulation reforms undertaken by most countries during the last few years have had important effects on the conduct of monetary policy in the region. In particular, Central Bankers have had to learn how to manipulate monetary policy through indirect instruments, as opposed to the traditional quantitative control of credit. For example, the reduction and harmonization of reserves requirements has increased commercial banks ability to intermediate funds, reducing the authorities' direct control on liquidity. Likewise, gradual elimination of direct credit allocation practices has forced monetary authorities to devise alternative methods for monetary control. Different countries have opted for different solutions. The most advanced ones-Chile, Mexico, Argentina, for example-have been able to develop an increasingly sophisticated system of open market operations, while others have increasingly relied on the use of "monetary stabilization" securities issued by the Central Bank.

The opening of the Latin American economies to international transactions-both in goods and financial assets-has also introduced some changes in the way monetary policy is conducted in the region. In particular, Central Bankers have found out that in an open economy policy inconsistencies can be very costly. Also, it has become clear that in an open environment, changes in the domestic economic conditions can generate sizeable capital movements that greatly impact on monetary policy. For example, the 1991-92 surge in capital inflows into the region has resulted in large increases in the supply of money that, in many cases, have frustrated the Central Banks monetary programs and have generated pressures towards real exchange rate appreciation. ${ }^{18}$ As the Colombian authorities found out in 1991, in an open economy it even becomes difficult to sterilize the increases in international reserves. When this is attempted through the sale of domestic bonds, interest rate differentials are bound to appear, creating additional incentives for capital to flow into the country further increasing the quantity of money. 19

18 The increase in capital inflows has also impacted on real exchange rates throughout the region. See chapter 5 for a discussion on the subject.

19 See Calvo (1991) for an analytical discussion along these lines. 
To sum up, the analysis presented in this section suggests that the fact that most Latin American nations did not follow the often-recommended "stabilization first" sequencing, does not appear to have hurt in a serious way their adjustment programs. In spite of the losses in government revenues associated with the lowering of tariffs, the authorities in most cases were able to find alternative sources of revenue. As the evidence shows, most countries have in fact made important progress in fiscal adjustment and macroeconomic stabilization.

\section{Savings and Investment}

As can be seen in Table 1, most Latin American countries have implemented financial reforms as part of the broad structural adjustment reforms if the 1980s and 1990s. The early financial liberalization literature argued that one of the most important objectives of these reforms was to generate, among other things, a significant increase in domestic savings. In that regard, financial reforms would supplement the stabilization effort: increases in savings would help reduce current account imbalances. In the original models of financial repression of McKinnon(1973) and Shaw (1973), allowing (real) interest rates to rise to market levels altered the intertemporal rate of substitution, encouraging aggregate savings. ${ }^{20}$ However, empirical studies for a large number of countries-both advanced and developed-have found only a weak interest rate elasticity of aggregate domestic savings. Boskin (1978) found a very low elasticity for the United States. A number of studies for the case of the developing countries, including Giovaninni (1981) have failed to find any effect of interest rate changes on private savings. McKinnon (1991) has recently acknowledged that "aggregate savings, as measured in the GNP accounts, does not respond strongly to higher real interest rates" (p. 22). A number of hypotheses have been offered as possible explanations for this phenomenon. First, in financial models higher (real) interest rates will result in portfolio readjustments, including a higher degree of financial intermediation, but not necessarily on higher aggregate savings as defined in national accounts. Moreover, in general equilibrium macroeconomics settings an increase in interest rates will tend to have two offsetting effects on savings: on the one hand, there will be an intertemporal substitution effect away from

\footnotetext{
${ }^{20}$ See Fry (1988) for surveys of these type of models.
} 
current consumption, that will tend to increase domestic savings. On the other hand, higher interest rates will generate a negative wealth effect that will tend to reduce savings. ${ }^{21}$ Depending on which of these two forces dominates, higher interest rates will be associated with either an increase or a decline in aggregate savings.

The recent literature on economic reform has not dealt in detail on the relationship between savings and investment on the one hand, and trade reform on the other. There are, however, some clear links. First, anticipated changes in import tariffs (or export taxes, for that matter) will tend to have effects on the intertemporal consumption rate of interest and, thus, will affect savings (Razin and Svensson, 1983 and Edwards and van Wijnbergen 1986). If the public expects that import tariffs will be reduced in the future, it will tend to postpone present consumption and increase savings. What is perhaps more important, however, is that the opposite is also the case. If the private sector expects a future increase in tariffs - a situation likely to occur if the trade liberalization reform is not credible --, it will increase its current consumption, reducing tariffs. What is particularly interesting about this possibility is that it can generate a situation of self-fulfilled expectations. The decline in savings increases the current account deficit, which in turn results in lower credibility in the trade reform. Some authors have actually argued that this may have been the case in Chile in 1982 (Edwards and Cox-Edwards, 1991).

There is also a link between trade reform, stabilization and investment. Some authors have argued that since under high inflation, relative prices are highly volatile, investors will be reluctant to commit enough funds to investment projects. This situation is particularly serious under a trade reform program, since the success of the reform will require that investment increases in the new areas of comparative advantage (Fischer 1986). Existing empirical evidence indeed supports the contention that, with other things given, countries that rely more heavily on the inflation tax will have a lower investment to GDP ratio.

In spite of the relative unresponsiveness of savings to higher interest rates, financial reforms still have important potential effects on growth through improvement in the quality

\footnotetext{
${ }^{21}$ If the objective of savers is to receive a certain fixed income, higher interest rates lower the amount required to attain the income flow desired.
} 
of aggregate investment, and especially private investment. For example, in a series of studies Gelb (1989), Fry (1988) and McKinnon (1991) have found robust evidence supporting the proposition that a reduction in the degree of repression of the capital market will tend to increases the productivity of investment. Interestingly enough, this work also suggests that reducing financial instability, and especially inflation, will also have an important positive effect on the return to investment. Also, recent work by King and Levine (1993) provides support to the idea that more developed financial sectors have been associated with faster total factor productivity growth.

Figure 3 contains data on the evolution of domestic savings ratios for selected Latin American countries between 1980 and 1991. As can be seen, in the majority of the cases savings have increased with respect to the mid-1980s, but are still below their 1980 level. Chile and Mexico, two of the earliest reformers, provide contrasting cases. While in Chile gross domestic savings have increased steadily since 1980-partially as a result of the social security reform discussed above - reaching almost 23\% of GDP in 1991, in Mexico aggregate domestic savings have declined gradually during this period. Although it is too early to say what will be the final impact of the recent financial reforms on aggregate savings, there is a large body of evidence indicating that they will not generate a massive increase, in the short to medium run, as was thought by the early supporters of financial liberalization policies.

The evidence suggesting that savings have a low degree of responsiveness with respect to interest rates has prompted analysts and policy makers to consider altemative policy mechanisms to encourage savings. Some countries, such as Chile in the mid-1980s, relied on tax reforms aimed discouraging consumption. ${ }^{22}$ More recently a number of authors have suggested that shifting the tax base from income to consumption will encourage thrift in the economy as a whole. From an analytical point of view these policies rely on the assumption that there is a high intertemporal substitution in consumption. However, as pointed out above, the limited existing evidence does not support this contention and sheds

DThat provision was altered in the 1990 tax reform. See the discussion in Chapter 4. See, also, Edwards and Edwards (1991). 
FIGURE 3

\section{GROSS DOMESTIC SAVINGS / GDP RATIO}
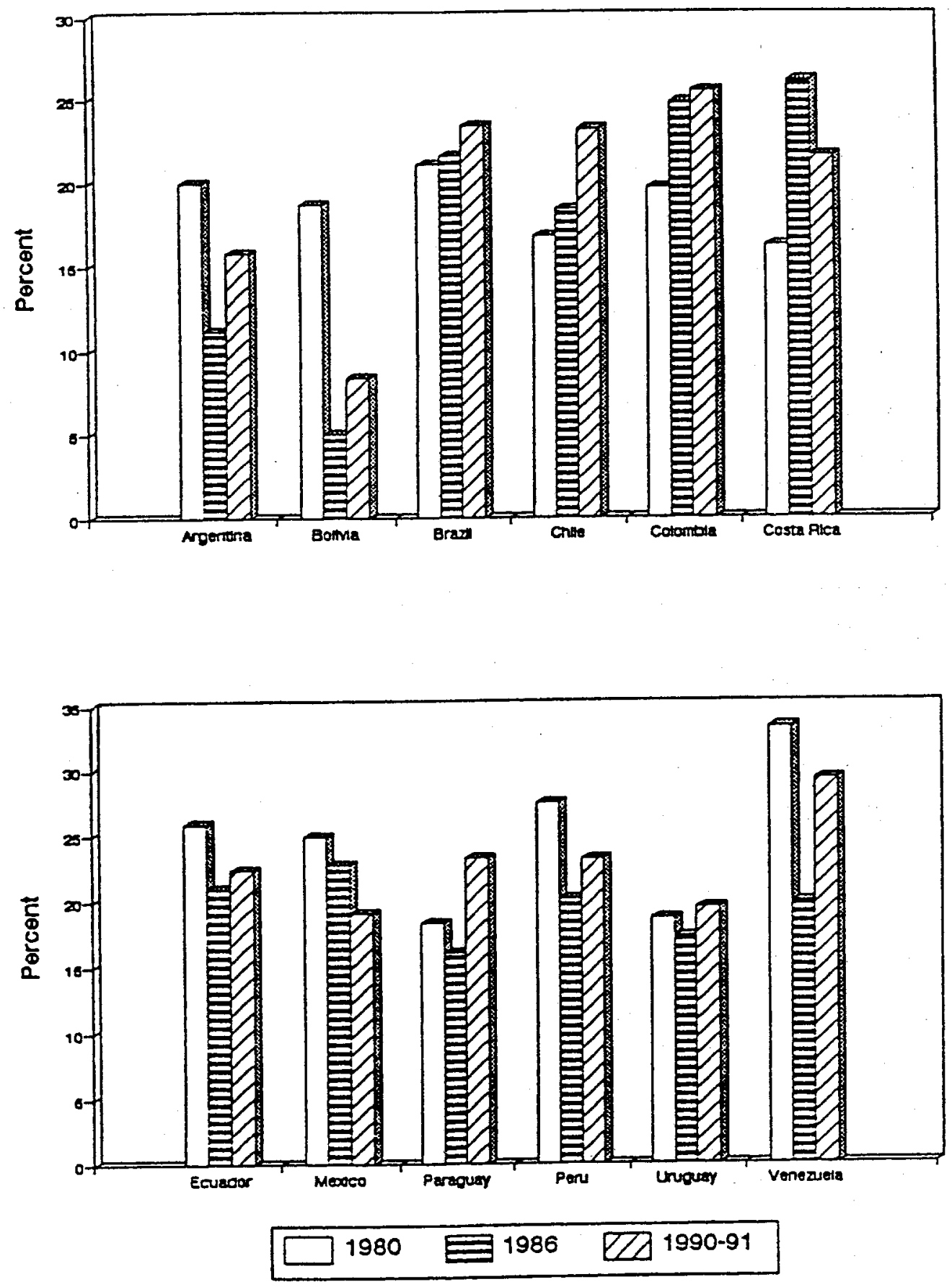

Source: World Bank, World Tables 
some doubts on the effectiveness of these tax-based mechanisms to increase aggregate savings. ${ }^{23}$

Evidence from a score of countries--including the East Asia miracle nations--suggests that the increase in private domestic savings ratios is a rather slow process (World Bank 1993). This evidence also indicates that a drastic increase of private savings has usually been the result of two factors: macroeconomic stability and the creation of an institutional environment that instills confidence on small savers--the case of postal savings in East Asia is a good example of this type of institution. This suggests that, to the extent that macroeconomic stabilization becomes consolidated, private savings will tend to increase. More importantly, however, this evidence suggests that the development of new institutions, such as new social security systems tailored after the Chilean experience, will play a fundamental role in increasing private savings from their historical levels.

The increase in government savings is a powerful way to raise aggregate domestic savings. In a comprehensive study Corbo and Schmidt-Hebbel (1991) used a thirteen-country data set to analyze the macroeconomic consequences of higher public savings. In particular, they investigated the extent to which an increase in government savings would be reflected in a decline in private savings. They found out that, although govermment savings crowd out private savings, the magnitude of this effect is far below the one-to-one relationship suggested by the simple Ricardian equivalence doctrine; overall their empirical analysis strongly indicates that an increase in public savings will be translated into higher aggregate savings. ${ }^{24}$ Corbo and Schmidt-Hebbel also found that, on average, increasing public savings via reduced expenditures is more effective than increasing taxation.

The most appropriate mix of higher tax revenues and reduced expenditures to increase public savings, will depend on the specific characteristics of the country in question. If the

${ }^{23}$ Of course, from a purely efficiency point of view it is still advisable to implement a tax system that generates the smallest possible number of distortions.

${ }^{24}$ On Ricardian-Barro equivalence, see Barro (1974). 
level of tax compliance is low, and the tax effort is clearly subpar, an increase in tax revenues will be called for. However, under most circumstances some reduction in expenditure is likely to be optimal. In most countries in the region it seems highly feasible to reduce the military budget as a way to both finance the expansion of social programs and the generation of higher public savings.

Some important recent research undertaken at the World Bank (1993) suggests that in East Asia there has been a virtuous circle between growth and private savings. Using time series econometric techniques, the Bank researchers have found that in the miracle countries higher growth increases disposable income, and encourages private savings. Higher savings, in turn, permits a higher level of capital accumulation, and thus, reinforces the higher growth. Of course, a key question in this context is how to get this virtuous circle going? The answer: increase public savings during the earlier phases of the process. This East Asia evidence then supports the view expressed above on the key note of public savings, and thus further fiscal adjustments, in Latin America during the years to come.

It is important to note that increasing government savings does not imply that these countries should, pari passu, increase public investment. In fact, both decisions should be kept separate. Whether or not specific public investments should be undertaken, should be decided on a project by project basis. This, as discussed with greater detail below, requires implementing highly professional procedures for appraising public investment projects. In those countries where an expansion in public investment is not justified, the government should still increase its savings, and channel those resources to the capital market.

\section{IV.1 Investment and Infrastructure}

Figure 4 contains data on the ratio of gross private investment to GDP for selected countries. As can be seen, in many of the cases it is possible to detect a familiar "U-shaped" behavior: private investment experienced a drastic dip in the mid-1980s, only to recover in the early 1990s. While in some countries the recovery has been complete, in others the private investment ratio is still significantly below its 1980 level-Bolivia, Colombia, Paraguay, for example.

However, the volume of private investment is only part of the story. In most countries there has been an significant change in the composition of private investment. For 
FIGURE 4

PRIVATE GROSS DOMESTIC INVESTMENT / GDP

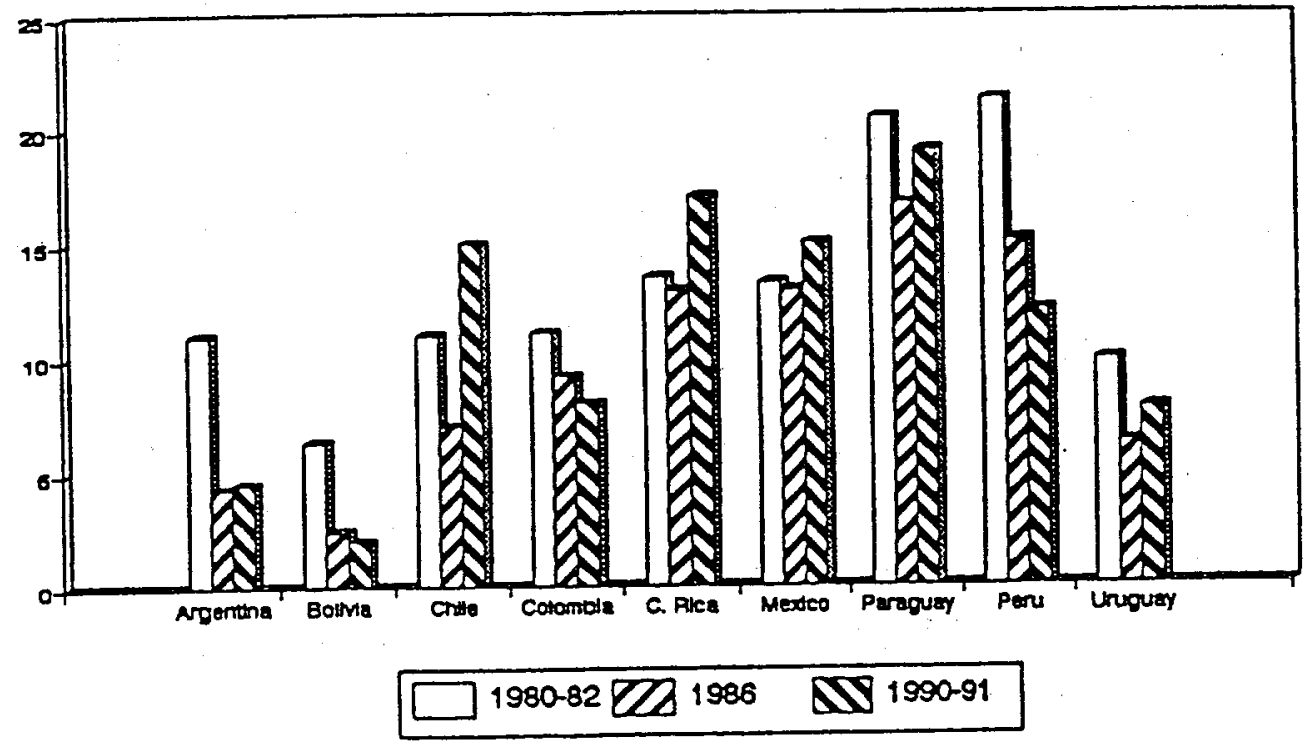

Source: World Bank, World Tables 
instance, after decades of stagnation, investment in agriculture and agriculture-related activities has soared in Chile. This has resulted in a surge in productivity growth and in an increase in agriculture-related exports from less than U.S. $\$ 40$ million in the early 1970 s, to almost U.S. $\$ 1.3$ billion in 1991 . Moreover, and as discussed in the preceding sections, the real return to investment in Chile has been extremely high in the past few years, helping generate a significant growth in the privately administered pension funds. A growing proportion of private investment has also been directed to the manufacturing sector, which has gone through a rapid expansion in export-related activities (Edwards and Cox-Edwards 1993).

In Mexico and Argentina the composition of private investment has also experienced significant changes in the past few years. For instance, in both countries important increases have been observed in investment in "nontraditional" activities and, especially in Mexico, a great effort has been made to restructure firms and increase their export potential. For example, Kessel (1992) has pointed out that the structural reforms have resulted in a significant restructuring of Mexico's petrochemical sector, with new investments in modern technologies that will allow the sector to withstand new competition and, in some product lines, move aggressively into exports. Also, in both Argentina and Mexico the private sector is now channeling an important percentage of its investment effort toward infrastructure, including privately run ports and roads.

Public investment was affected in a particularly severe way in the aftermath of the debt crisis. As Figure 5 shows, in most countries with available information, public gross domestic investment was significantly lower in 1990/91 than in 1980. Moreover, in a number of countries net public investment has been negative during the past decade. This has been the result of three interrelated factors. First, as discussed previously, the need to reverse the international transfer of resources in the early and mid-1980s forced almost every country in the region to reduce expenditures. In most cases public investment shouldered a disproportionate share of this adjustment. Second, as pointed out above, the fiscal adjustments of the late 1980 were largely accomplished through major reductions in public expenditures, including public investment. And third, the new reduced role of the state in the development process has also affected public investment; many activities that in the past 
FIGURE 5

\section{PUBLIC GROSS DOMESTIC INVESTMENT / GDP}

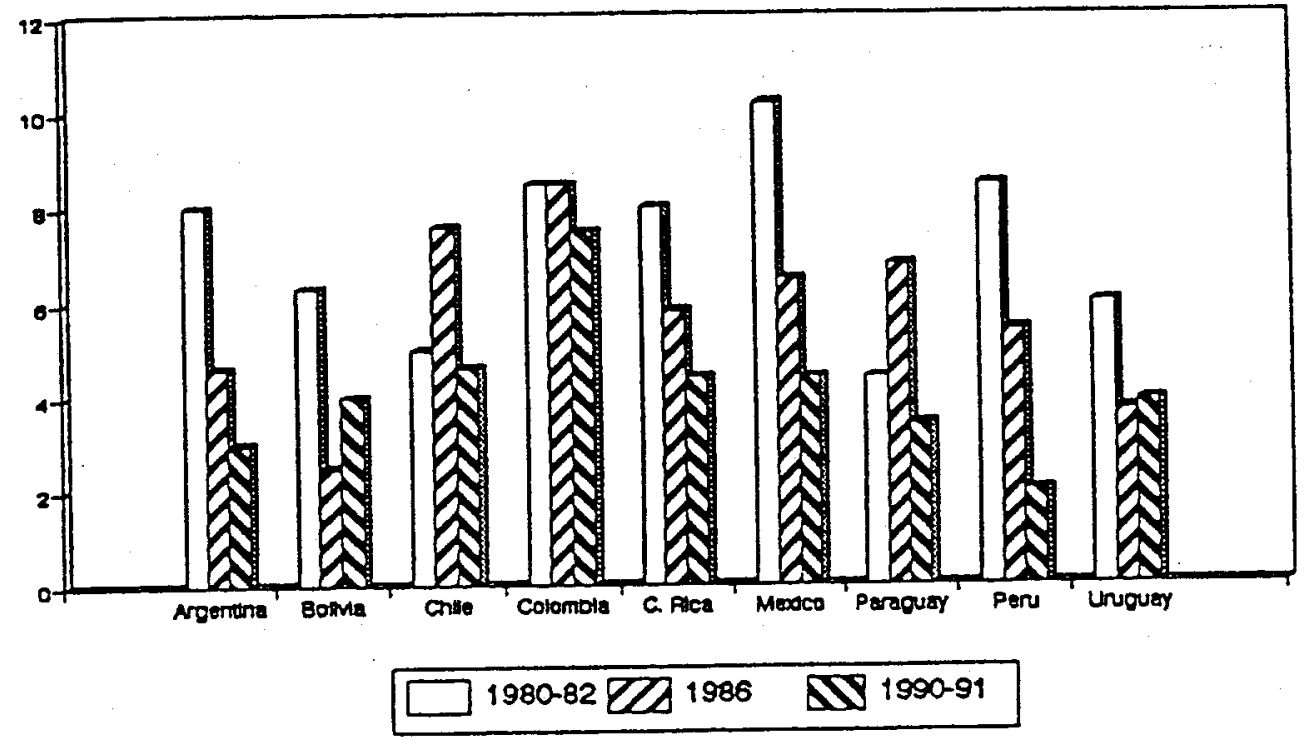

Source: World Bank, World Tables 
were considered to be exclusively within the realm of government activities-including utilities-are now performed by the private sector.

An important consequence of the decline in public investment during the $1980 \mathrm{~s}$ is the deterioration in the region's infrastructure, including roads, bridges, ports and power generation. ${ }^{25}$ Recent empirical studies for a number of countries-including the United States-have pointed out that investment in infrastructure has a particularly large effect on growth. For example, Aschauer (1989) has argued that due to the existence of significant externalities, infrastructure investment will have almost twice the effect on growth than private investment. These findings have prompted a number of policy makers-including the new Clinton administration in the United States-to emphasize the need to step up capital accumulation in basic infrastructure.

Although the externalities argument is eminently plausible for some type of infrastructure, it is very important not to push this idea too far. In fact, the economic history of Latin America is replete with cases of gigantic public sector projects-many of them on infrastructure-with very low, and even negative, social returns. In general, public sector investment projects should be assessed from a microeconomic perspective, and should only be undertaken to the extent that their (social) rate of return exceeds a certain predetermined level. Not following this rule is a clear invitation for retuming to the practices of the past, where exceedingly frivolous projects were implemented in the name of some allegedly worthy cause.

One of the more startling aspects of public sector investment in Latin America is that most countries have extremely low budgets for maintenance and operation. This has resulted, throughout the region, in an extremely rapid rate of deterioration of the stock of capital. What makes this situation particularly serious is that maintenance outlays are typically small relative to investment costs, and have extremely high (social) rates of retum. Preliminary analyses suggest that one of the most effective ways to improve the quality of

\footnotetext{
${ }^{25}$ For a discussion on the state of infrastructure in the Latin American region see, for example, Fleisig (1992).
} 
infrastructure in the region is by expanding the maintenance and operations budgets. ${ }^{26}$ Paradoxically, however, constraints placed on lending in many of the multilateral institutions discourage a more efficient and extensive use of maintenance. Changes in these regulations, that would allow multilateral institutions to co-finance maintenance would go a long way toward ensuring a marked improvement in the quality of the region's infrastructure in the years to come.

\section{IV.2 Direst Foreign Inyestment}

For many years the Latin American countries imposed serious restrictions on direct foreign investment. For instance, in the early 1970s the countries of the Andean Pact implemented a regulation-Resolution 24 of the Cartagena Accord- that seriously restricted foreigners rights to control manufacturing firms, and placed broad controls on their ability to remit profits to their home countries. In other cases, foreigners could not participate in some sectors deemed "strategic". As a result of these regulations, and of the inward looking policies pursued in most countries, direct foreign investment played a very minor role in the process of capital accumulation in the region during the 1970s; in most countries it amounted, on average, to less than one percent of GDP per year (Edwards 1991).

Many analysts have argued that in the aftermath of the debt crisis, direct foreign investment should play a growing role as a source of foreign funds for the less advanced countries. However, the total volume of resources is likely to be limited and will have to be shared by an increasingly larger number of potential "host countries", including the nations of Eastern Europe and Central Asia. For example, after pointing out that bank loans and bonds issues are unlikely to be a major source of foreign funds during the years to come, Cardoso and Dombusch (1990) argue that "the immediate obvious candidate [for providing foreign resources] is direct foreign investment. Unfortunately, the role of direct foreign investment has never been very large" (p. 1434).

Increasingly, however, analysts agree that a fundamental role of DFI is allowing the host country to become in contact with new techniques and new management styles. In short, even if its volume is modest, DFI plays an important role in helping with the diffusion

\footnotetext{
${ }^{20}$ See Fleisig (1992).
} 
of innovations, encouraging the imitation of best practices in more advanced countries, and helping generate a more rapid pace of productivity growth.

Under these circumstances, a key question is what makes particular countries attractive for foreign investors? A first, and obvious, factor refers to the regulations directly affecting DFI activities, including restrictions on the remittances of profits. In recent years most Latin American countries have introduced significant reforms to their DFI legislations: instead of foreign firms being chased out of these countries as in the 1960s and 1970s, foreign companies are now being lured in through a variety of schemes (TMF 1992). For example, in 1990 a new law ensuring equal treatment for foreigners and locals in all sectors, with the exception of mining and hydrocarbons, was approved in Bolivia; Venezuela went through successive rounds of liberalization of direct foreign investment restrictions between 1989 and 1990; and Brazil greatly relaxed the restrictions on the repatriation of profits in mid-1990. Table 9 presents a summary of the current regulations affecting direct foreign investment in selected countries in the region. As can be seen, these are quite liberal and contrast sharply with those of the 1960s and 1970s (Eaton 1993).

A number of studies have indicated that one of the most important determinants of the distribution of DFI across countries is the soundness of economic policies. Foreign investors will tend to stay away from countries with major distortions and controls, and will be attracted to those nations with consistent and predictable macroeconomic policies. For example, in a recent study based on a fifty eight-country data set, Edwards (1991) found out that policies that move the economy toward greater openness and international competitiveness, as well as reduce the size of the government, will tend to have an important positive effect on DFI. In that regard, the reforms undertaken in most of the Latin American countries during the past few years have positioned them very well as possible recipients of direct foreign investment funds. This has indeed been the case in some of the early reformers-Chile and Mexico-which have seen drastic increases in DFI in the past few years-see Figure 6 for data on a group of Latin American countries. It should be noted, however, that even in these cases DFI is still a relatively small proportion of GDP, indicating the desirability of efforts to increase domestic savings in the Latin American region. 


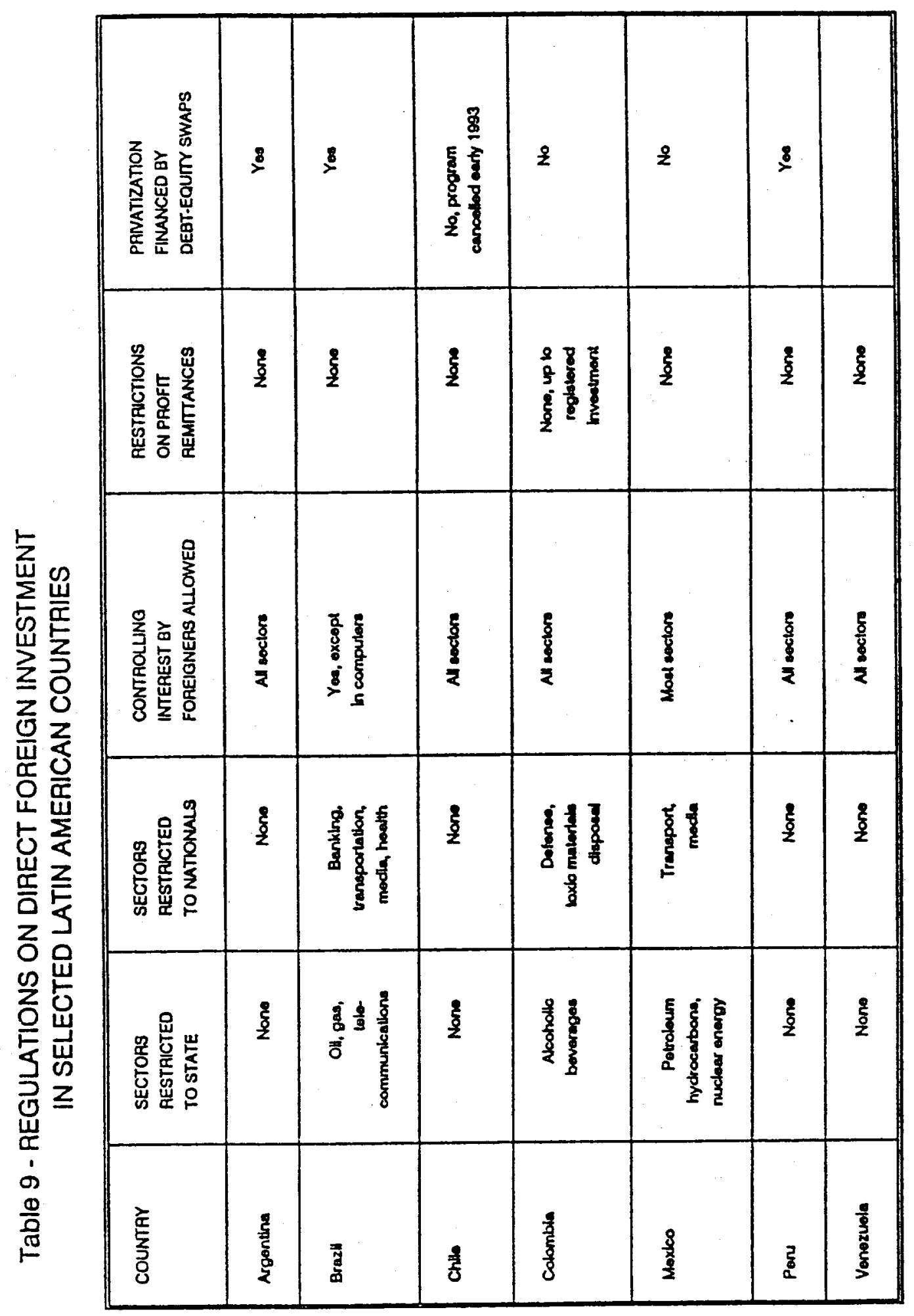

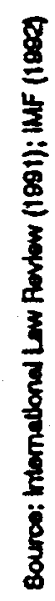


FIGURE 6

NET FOREIGN DIRECT INVESTMENT / GDP
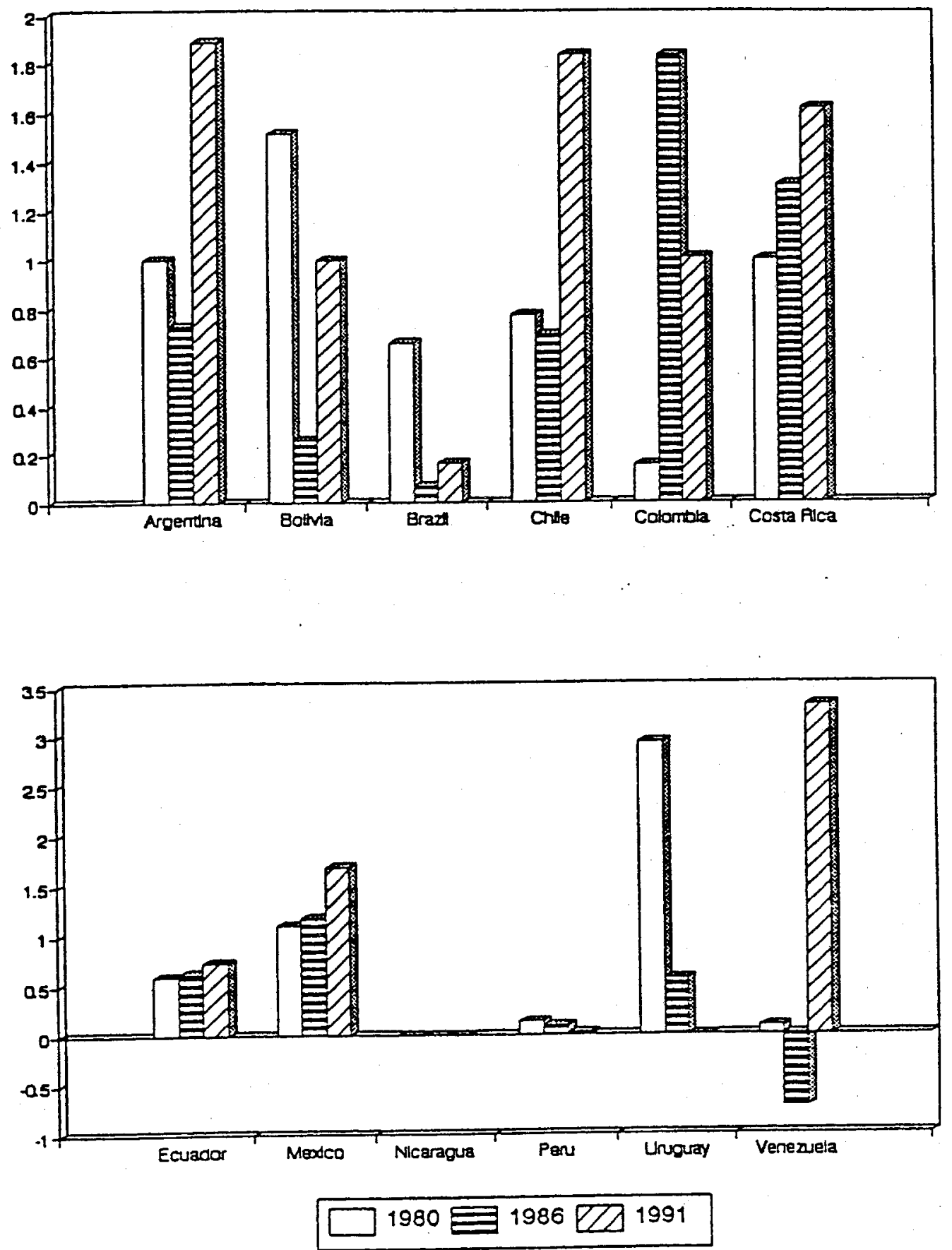

Source: IMF through 1990, World Bank for 1991. 
V. Exchange Rates, Disinflation and Trade Liberalization

As many Latin countries have painfully learned, in the long run it is not possible to maintain a fixed nominal exchange rate under conditions of major fiscal imbalances financed by domestic credit creation. If domestic inflationary pressures exceed "the" international rate of inflation, international reserves will decline, overvaluation will take over, and a speculative attack on the Central Bank foreign exchange holdings will eventually take place. ${ }^{n}$ A number of countries in the region that historically suffered from chronically high inflation dealt with this situation by adopting an adjustable, or crawling peg, system characterized by periodical adjustments of the nominal exchange rate according to inflation rate differentials. The motivation behind this type of system, first adopted by Brazil, Colombia and Chile during the 1960 s, is the recognition that given an expansive fiscal stance, it is not possible to maintain a competitive real exchange rate with a fixed nominal exchange rate system.

The historical experiences of these countries contrasts sharply with that of another group of Latin American nations, mostly in Central America and the Caribbean, that for many years had fixed exchange rates and low inflation rates. Interestingly enough, in the late 1970 s, almost a decade after the collapse of the Bretton Woods system, a significant number of Latin American countries still had a fixed exchange rate systems. ${ }^{23}$ This situation, however, changed after the debt crisis. Under heavy internal and external pressure, almost every country in the region had to adopt some kind of managed exchange rate regime during the mid-1980s - see Table 10.

Initially, the adoption of more flexible exchange rate systems in Latin America was greeted with great enthusiasm by policymakers and experts alike. ${ }^{20}$ It was argued that

27 There is now an extensive literature on speculative attacks under fixed exchange rates. The pioneering piece is Krugman (1979). See Edwards (1989a) for a number of case studies on the subject.

28 The International Financial Statistics report that in 1979 thirteen Latin American countries had a fixed exchange rate with respect to the U.S. dollar.

29 See Williamson (1981) for a forceful defense of the crawling peg exchange rate regime. 


\section{Table 10 - FIXED EXCHANGE RATE COUNTRIES IN LATIN AMERICA}

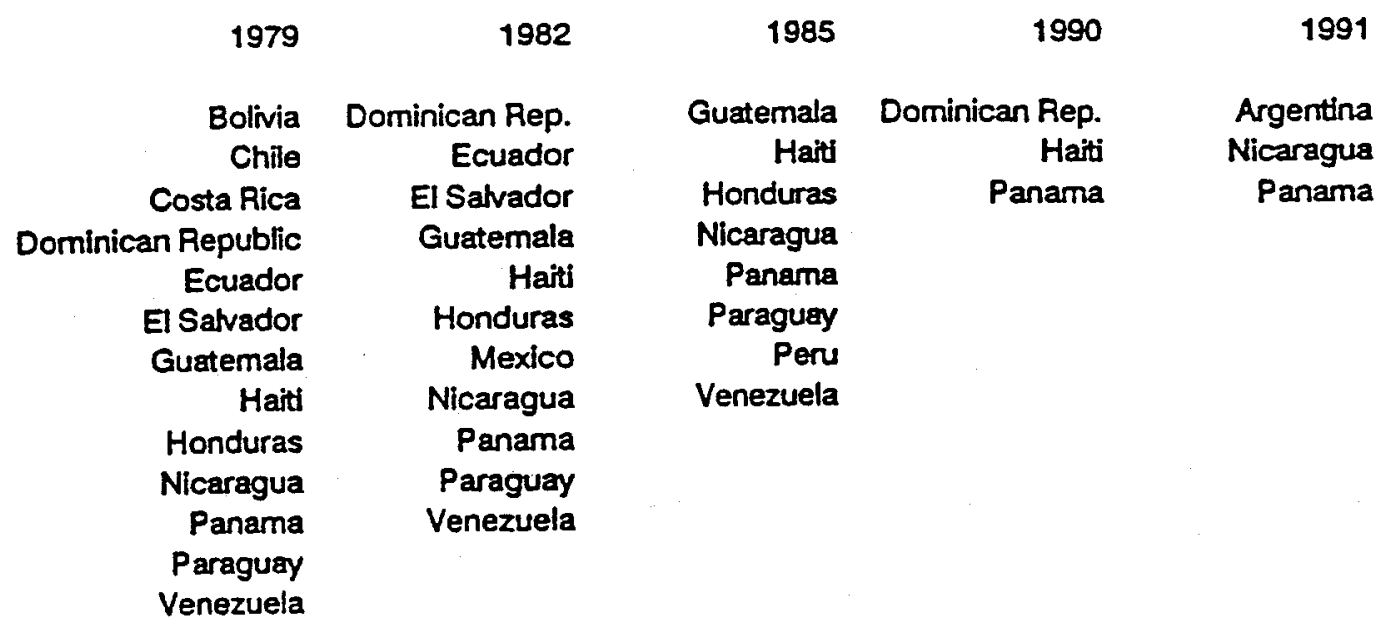

Source: International Monetary Fund 
crawling peg regimes provided an adequate way to isolate the real sector from the effects of external shocks and domestic inflation. However, this generalized enthusiasm for sliding parities was short lived. In the early 1990 s a number of observers, including the staff of the IMF, began to argue that flexible exchange rates were allowing the Latin American countries to accommodate inflation and institutionalize indexation, discouraging the implementation serious anti-inflationary programs. According to this view, exchange rate policy in Latin America should return to greater rigidity-and even complete fixity-as a way to introduce financial discipline and credibility, eliminate inertia and provide an anchor for prices. ${ }^{30}$

The proposition that fixed exchange rates should become an integral component of the region's efforts to achieve macroeconomic stability has generated a number of questions among policymakers and their advisers: How is this system exactly supposed to work? How has it actually performed in history? What are the tradeoffs between fixed rates and a more flexible system? Do preannounced declining pegs, of the "tablita" type, operate in a similar way? If a fixed exchange rate is adopted, how should the transition to this regime be engineered? How does this system affect real exchange rate behavior and competitiveness?

As discussed in Section II of this paper, however, the most serious issue refers to the compatibility between a fixed exchange rate system and a liberalized foreign sector. More specifically, the policy literature on trade reform has pointed repeatedly that avoiding real exchange rate overvaluation is at the center of a successful reform. Is it possible, then, to achieve disinflation and maintain real exchange rate competitiveness? Some of these issues are addressed in this section.

\section{V.1 Exchange Rates as Anchors: Analytical Aspects}

Much of the recent enthusiasm for fixed nominal exchange rates is intellectually rooted on the modern credibility and time consistency literature. According to this approach,

30 This view, or some variant of it, has been adopted by a number of Latin American countries in the last two decades-for instance in the Southern Cone during the 1970s, in Nicaragua in 1991, in Argentina since 1991, and to some extent in Mexico since 1988-with different degrees of success. History, however, has unequivocally shown, that quite independently of other factors, if public finances are not tightly controlled the adoption of an exchange rate anchor policy is doomed to fail. 
which was pioneered by Calvo (1978), and Kydland and Prescott (1977), governments that have the discretion to alter the nominal exchange rate will tend to abuse their power, introducing an inflationary bias into the economy. The reason for this is that under a set of plausible conditions, such as the existence of labor market rigidities that preclude the economy from reaching full employment, it will be optimal for the government to "surprise" the private sector through unexpected devaluations. By engineering these unexpected devaluations the government hopes to induce a reduction in real wages and, thus, an increase in employment and a boost in output. Naturally, in equilibrium the public will be aware of this incentive faced by the authorities, and will react to it by anticipating the devaluation surprises and hence rendering them ineffective. As a consequence of this strategic interaction between the government and the private sector, the economy will reach a high inflation plateau.

A key policy implication of this literature is that, along the lines of the fiscal adjustment discussion presented above, defining (and implementing) constraints that will make government pre-commitments credible, will result in an improvement in society's welfare. It is here where fixed exchange rates come into the picture. It has been argued that the adoption of a fixed exchange rate will constrain governments ability to surprise the private sector through unexpected devaluations. Promises of fiscal discipline will become credible and private sector actions will not elicit successive rounds of inflationary actions. ${ }^{31}$ In particular, it has been argued that fixed exchange rates provide a reputational constraint on government behavior. The authorities know that if they undertake overly expansive credit policy they will be forced to abandon the parity and devalue. As the 1993 crisis of the ERM has shown, exchange rate crises can indeed shatter the reputation of politicians.

In spite of its elegant appeal, this view has, in its simplest incarnation, some problems. First, in these simple settings exchange rate policy has a very limited role. In fact, in most of these models its only effect is to alter the domestic rate of inflation and, through it, the government perceives it as altering real wages. However, in most modern

31 See Persson and Tabellini (1990) and Edwards (1993b) for discussions along these lines. 
exchange rate models, nominal devaluations can also help accommodate shocks to real exchange rate fundamentals-including shocks to the terms of trade-helping to avoid RER misalignment. ${ }^{32}$ Second, in economies with stochastic shocks, contingent exchange rate rules can, at least in principle, be superior to fixed rates (Flood and Isard, 1989). Third, it is not clear why a country that can credibly commit itself to unilaterally fixing the exchange rate, cannot commit itself to maintaining a fixed stock of domestic money.

In recent papers, Devarajan and Rodrik (1992) and Kamin (1991), among others, have addressed the question of the desirability of fixed exchange rates from a more general perspective. For example, in Devarajan and Rodrik (1992), policymakers face a tradeoff regarding exchange rate policy: while exchange rate flexibility has an inflationary bias, it also allows the country to reduce output variability. This is accomplished by smoothing, via exchange rate adjustments, the consequences of terms of trade shocks on output. In this model it is not possible to rank a-priori fixed and flexible (or active) exchange rate regimes. For large terms of trade shocks it is more likely that flexible exchange rates will be superior. Likewise, the more vulnerable the real economy is to these terms of trade shocks, the more desirable will flexible arrangements become. On the other hand, the greater is the government's built-in inflationary bias, the greater will be its temptation to abuse devaluations, and the less desirable will a flexible arrangement become.

John Williamson (1991) has recently dealt with the issue of exchange rate regimes in developing nations. He has argued that a fixed exchange rate would be advisable as long as four conditions are met: (1) the country in question is "small" relative to the rest of the world; (2) the bulk of its international trade is undertaken with the country (or countries) with respect to which it plans to peg its currency; (3) the country wishes to have a rate of inflation similar to that of the country it is pegging its currency to; and (4) there are institutional arrangements that assure that the commitment to a fixed rate is credible. Williamson goes on to argue that, once these four conditions are met, the only remaining argument in favor of flexible exchange rates refers to terms of trade shocks. Although Williamson's list of requirements for a successful fixed exchange rate is eminently plausible,

32 See Dombusch (1991), Edwards (1989a). 
it leaves a number of unanswered questions. In particular, his analysis is silent on whether the adoption of fixed exchange rates provides, on and by itself, an institutional constraint on fiscal policy. More specifically, Williamson's discussion does not address the issue of whether the existence of a fixed exchange rate imposes reputational or other type of constraints on politicians (see also Corden 1972).

\section{V.2 Latin American Experiences with Nominal Exchange Rate Anchors}

The evaluation of fixed exchange rates as nominal anchors in real world situations, should concentrate on two features of this system. First, to what extent have these regimes constrained governments behavior in the long run? And, second, how do these regimes work during the transition from high to low inflation? More specifically, does the adoption of a fixed exchange rate indeed accelerates the convergence of the domestic rate of inflation to "world" levels?

Some studies have recently addressed these issues for the case of the Latin American nations. ${ }^{33}$ For example, a recent study on the long run experiences of four Latin American nations-the Dominican Republic, El Salvador, Honduras and Guatemala-with fixed exchange rates, suggests that the existence of a very long tradition of exchange rate stability provided some constraints on Central Bank behavior in these countries. ${ }^{34}$ Between 1950 and 1973 these central banks were careful not to violate the constraints imposed by the existence of a fixed parity. However, the historical evidence also indicates that these constraints are not fully operational under severe pressure stemming from terms of trade shocks. For example, in these four countries the limits imposed by fixed rates on domestic credit creation became non-binding during the late 1970s and 1980s, and could not survive the combination of populist political pressures and severely negative terms of trade shocks. As a result of overly expansive policies typical crisis situations evolved. However, the authorities artificially clung to the fixed rates for as long as they could. The empirical

33 See, for example, Kiguel and Liviatan (1992), Edwards (1993a,b).

34 These countries provide a unique opportunity for studying the behavior of fixed exchange rates. They have had the longest uninterrupted experiences in the world with fixed parities. See Edwards (1993b) for details. 
evidence clearly suggests that by trying to avoid exchange rate adjustment after the debt crisis, and in light of the obvious imbalances, these nations were unable to engineer a rapid adjustment and incurred in severe costs in the form of exchange rate overvaluation, controls and trade distortions. Although not fully conclusive, these four historical episodes suggests that in an international environment characterized by large shocks exchange rate flexibility can greatly help smooth the adjustment.

Regarding the performance of nominal exchange rate anchors in a stabilization package, recent evidence suggests that even if the fiscal deficit is under control, this type of policy is likely to generate some degree of real exchange rate appreciation during the transition -- see Calvo et al. (1992) for a detailed discussion of the recent Latin American experience with increased capital inflows. ${ }^{35}$ Whether this will become a major policy problem, and will eventually force the abortion of the program, will depend on a number of factors including the initial level of the real exchange rate, the existence of policies aimed at deindexing other contracts, and the behavior of real exchange rate fundamentals.

An exchange rate anchor will be more effective when it is adopted from a situation of undervaluation, and be accompanied not only by consistent fiscal policies, but also by strong and convincing deindexation policies. This was the case, for example, in Mexico during 1988-91, and in Nicaragua between mid-1991 and 1992. If, however, other contracts, and especially wages, continued to be indexed with respect to past inflation the system will maintain a considerable degree of inertia, generating a sizeable depreciation as in Chile during the late 1970 s. If this type of situation is not managed carefully the country can run into a very serious situation, where a speculative attack on the currency will provoke a major crisis, and a return to macroeconomic instability. The appendix to this paper addresses these issues in detail.

Although the merits of fixed exchange rates will vary from country to country, it is possible to make some general statements. Both analytical work and historical evidence in Latin America and East Asia suggest that in countries that face large external shocks- either

${ }^{35}$ This was, for example, the case of Chile between 1978 and 1982. See Edwards (1993c), Dornbusch (1992), and Bruno (1991). 
terms of trade or financial shocks--a more flexible exchange rate policy allows the accommodation of those disturbances, and permits avoiding situations of real exchange rate overvaluation. In fact, recent comparative studies have persuasively shown that the maintenance of competitive real exchange rates has been at the heart of East Asian countries' splendid performance of the last few decades. On the other hand, under flexible (or administered) exchange rates there is always the danger that the authorities will exhibit a devaluationary and inflationary bias. In this case they will abuse their discretionary power, devaluing at a faster rate than required. This danger, however, can be greatly reduced through the creation of rules that place exchange rate policy in institutions removed from the contingent political cycle. This is the case, for example, in Chile, where exchange rate policy is undertaken by the independent Central Bank. ${ }^{36}$ Also, as Calvo (1989) has argued, the existence of indexed government debt--or more precisely foreign currency denominated debt--provided another disincentive for over devaluing in exchange rate regimes characterized by (some degree of) discretion and flexibility.

\section{V.3 Recent Real Exchange Rate Behavior in Latin America}

In the last years, competitive real exchange rates have been at the center of the vigorous performance of most of Latin America's external sectors. In fact, it is not an exaggeration to say that the trade reforms have been driven by highly competitive real exchange rates, that have made Latin products very attractive in world markets. Recently, however, in most Latin countries real exchange rates have experienced rapid real appreciations and losses in competitiveness (Figure 7). These developments have generated considerable concern among policymakers and political leaders.

These real appreciations (and losses in international competitiveness) have been the result of two basic factors: first, the use, in many countries of the exchange rate policy as an anti-inflationary tool -- in the spirit of the nominal anchors approach discussed above --

${ }^{36}$ Interestingly enough, Mexico's recent proposed legislation on the creation of an independent Central Bank maintains exchange rate policy in the hands of the Ministry of Finance. 
Flgure 7

REAL EFFECTIVE EXCHANGE RATES

$(1985-100)$

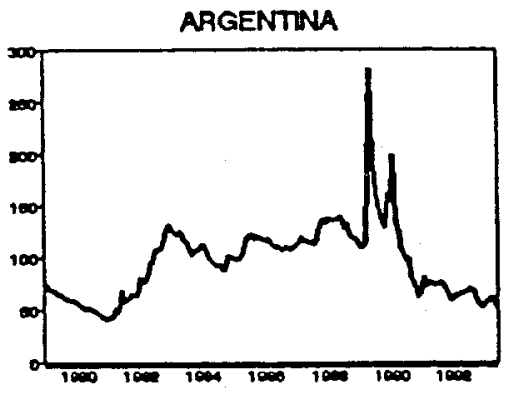

BRAZI

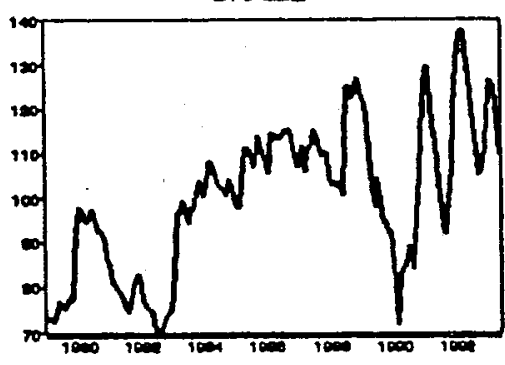

CHILE
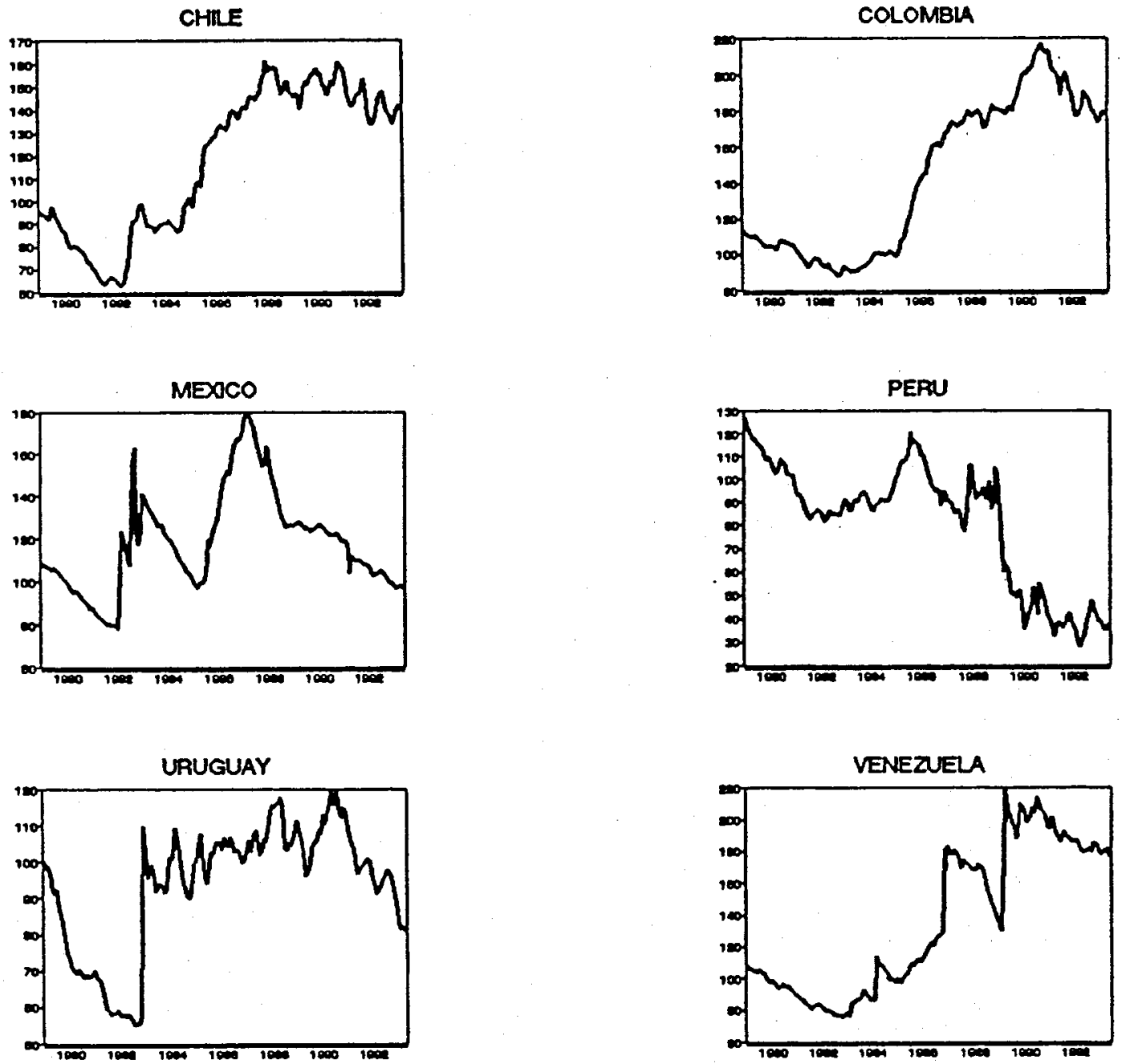

An increase In the Index reprosents a roal deprecietion; a docrease stands for a roel appreciation.

Source: Intemational Financial Statistics, IMF 
and, second, massive capital inflows into Latin America that have made foreign exchange "overabundant".

As pointed out above, one of the most serious limitations of the nominal exchange rate anchor policy is that, under almost every circumstance, once the exchange rate is fixed, other prices - including wages - will continue to increase, generating a change in relative prices in favor of nontradables. This has indeed been the case in both Argentina and Nicaragua, the two countries in the region that have adopted strictly fixed exchange rates as a way to drastically reduce inflation. In both cases the stabilization programs were based on a severe fiscal correction that virtually eliminated the fiscal deficit, in restrictive credit, and in a nominal exchange rate anchor. Although this policy succeeded in both countries in greatly reducing inflation, it has resulted in serious relative price misalignment. In Argentina this has been reflected in the fact that wholesale price inflation, which is heavily influenced by tradables, is only $3 \%$ per year, while consumer price inflation - highly dependent on nontradables - exceeds $18 \%$ per year. In Nicaragua tradable-related inflation rates have been very low (in the order of 2-3 percent) while nontradable inflation has exceeded $30 \%$ in the last 12 months.

As pointed out obove, Mexico followed a variant of the exchange rate anchor policy, announcing a predetermined rate of devaluation at a pace deliberately below ongoing inflation. The purpose of this policy has been to both anchor tradables prices and reduce expectations. However, since domestic inflation has systematically exceeded the predetermined rate of devaluation, Mexico has experienced a sizable real appreciation which has exceeded $35 \%$ between 1985 and mid-1992. The Mexican authorities have recently tried to face this problem by accelerating the daily rate of devaluation of the peso from 20 cents to 40 cents. A number of observers, however, have argued that this is not enough, and that in order to restore the required level of international competitiveness to Mexican exports the rate of nominal devaluation should be significantly faster than 40 cents a day.

The second cause behind the recent generalized real appreciations in Latin America has been the large increase in capital inflows into the region in the last two years. As Table 11 shows, after eight years of negative resource transfers, there has been a significant turnaround in 1991-92. This increased availability of foreign funds has affected the real 


\section{Table 11 - CAPITAL INFLOWS AND NET RESOURCE TRANSFERS: LATIN AMERICA 1981-1992}

$\begin{array}{rrrrr} & & \begin{array}{c}\text { NET CAPITAL } \\ \text { INFLOWS }\end{array} & -\begin{array}{c}\text { INTEREST AND } \\ \text { PROFIT INCOME }\end{array} & \begin{array}{c}\text { NET RESOURCE } \\ \text { TRANSFERS }\end{array} \\ 1982-85 \text { (a) } & 55.3 & -111.7 & -56.4 \\ 1986-89 \text { (a) } & 33.5 & -138.7 & -105.2 \\ 1990 & 17.0 & -35.7 & -18.7 \\ 1991 & 36.3 & -31.1 & 5.2 \\ 1992 \text { (b) } & 42.8 & -21.2 & 21.6\end{array}$
(a) Annual average
(b) Projection

Source: Jaspersen (1992) 
exchange rate through increased aggregate expenditure. A proportion of the newly available resources has been spent on nontradables - including in the real estate sector - putting pressure on their relative prices and on domestic inflation. An interesting feature of the recent capital movements is that a large proportion corresponds to portfolio investment and, relatively little is direct foreign investment. Table 12 provides net capital inflows data by country. As can be seen Mexico has been the most important recipient of foreign funds in the region in the last years. It has indeed been this very large availability of foreign financing what has allowed that country to have a current account deficit of the order of 5-6 percent of GDP. An important question, however, is whether this situation will be sustainable through time, or if it a decline in the level of funds available is foreseen for the near future.

Real exchange rate appreciations generated by increased capital inflows is not a completely new phenomenon in Latin America. In the late 1970 s most countries in the region, but especially the Southern Cone nations, were flooded with foreign resources that led to large real appreciations. The fact that this previous episode ended in the debt crisis has added dramaticism to the current concern on the possible negative effects of these capital flows.

Whether these capital movements are temporary - and thus subject to sudden reversals as in 1982 -- is particularly important in evaluating their possible consequences. In a recent study Calvo, Leiderman and Reinhart (1992) argue that the most important causes behind the generalized inflow of resources are external. In particular, their empirical analysis suggests that the recession in the industrialized world and the reduction in U.S. interest rates are the two main reasons that have triggered these capital movements. These authors suggest that once these world economic conditions change, the volume capital of capital flowing to Latin America will be reduced. This means that at that point the pressure over the real exchange rate will subside and a real exchange rate depreciation will be required.

The countries in the region have tried to cope with the real appreciation pressures in several ways. Colombia, for instance, tried to sterilize the accumulation of reserves by placing domestic bonds (OMAs) in the local market in 1991. However, in order to place 
Table 12 - NET CAPITAL INFLOWS AS PERCENTAGE OF GDP IN SELECTED LATIN AMERICAN COUNTRIES

$\begin{array}{lccccccccccc}\text { COUNTRY } & 1982 & 1983 & 1984 & 1985 & 1986 & 1987 & 1988 & 1989 & 1990 & 1991 \\ \text { Argentina } & 2.4 & 0.5 & 3.0 & 2.9 & 1.8 & 2.6 & 3.9 & 0.2 & 1.0 & 6.3 \\ \text { Brazil } & 4.2 & 2.1 & 1.8 & 0.1 & 0.6 & 1.3 & -0.5 & 0.4 & 1.3 & 0.2 \\ \text { Chile } & 4.4 & 2.3 & 8.3 & 5.0 & 3.0 & 3.7 & 3.7 & 4.3 & 7.8 & 2.5 \\ \text { Colombia } & 6.5 & 4.1 & 2.6 & 5.9 & 2.9 & 0.0 & 2.1 & 1.0 & 0.0 & 2.8 \\ \text { Mexico } & 5.6 & -1.5 & -0.6 & -1.2 & 0.7 & -0.7 & -0.8 & 0.8 & 5.0 & 10.6 \\ \text { Peru } & 5.7 & 2.4 & 3.4 & 1.1 & 2.1 & 2.3 & 3.5 & 1.5 & 2.4 & 9.5 \\ \text { Venezuela } & -2.5 & -6.6 & -3.6 & -1.8 & -1.9 & 0.8 & -1.5 & -5.7 & -4.1 & 4.9\end{array}$

Source: Economic and Social Progress in Latin America, IDB, 1992. 
these bonds the local interest rate had to increase making them relatively more attractive. This generated a widening interest rate differential in favor of Colombia, which attracted new capital flows that, in order to be sterilized, required new bond placements. This process generated a vicious cycle that contributed to a very large accumulation of domestic debt, without significantly affecting the real exchange rate. This experience shows vividly the difficulties faced by the authorities wishing to handle real exchange rate movements. In particular, this case indicates that real shocks - such as an increase in foreign capital inflows - cannot be tackled successfully using monetary policy instruments.

Argentina has recently tried to deal with the real appreciation by engineering a "pseudo" devaluation through a simultaneous increase in import tariffs and export subsidies. Although it is too early to know how this measure will affect the degree of competitiveness in the country, preliminary computations suggest that the magnitude of the adjustment obtained via tariffs-cum-subsidies package may be rather small. Mexico has followed a different route, and has decided to postpone the adoption of a completely fixed exchange rate. In October of 1992 the pace of the daily nominal exchange rate adjustment was doubled to 40 cents. As in the case of Argentina, it is too early to evaluate how effective these measures have been in dealing with the real appreciation trend. However, as pointed out earlier, a number of analysts of the Mexican scene have already argued that this measure clearly not enough.

Chile has tackled the real appreciation by implementing a broad set of measures, including conducting exchange rate policy relative to a three currencies basket, imposing reserve requirements on capital inflows and undertaking limited sterilization operations. In spite of this multi-front approach, Chile has not avoided real exchange rate pressures. Between December of 1991 and July 1992 the Chilean bilateral real exchange rate appreciated almost $10 \%$. As a result of this, exporters and agriculture producers have been mounting increasing pressure on the government for special treatment, arguing that by allowing the real exchange rate to appreciate an implicit contract has been broken. This type of political reaction is, in fact, becoming more and more generalized throughout the region, adding a difficult social dimension to the real exchange rate issue. 
Although there is no easy way to handle the real appreciation pressures, historical experience shows that there are, at least, two possible avenues that the authorities can follow. First, in those countries where the dominant force behind real exchange rate movements is price inertia in the presence of nominal exchange rate anchor policies, the adoption of a pragmatic crawling peg system will usually help. This means that, to some extent, the inflationary targets will have to be less ambitious as a periodic exchange rate adjustment will result in some inflation. However, to the extent that this policy is supplemented by tight overall fiscal policy there should be no concern regarding inflationary explosions.

Second, the discrimination between short term (speculative) capital and longer term capital should go a long way in helping resolve the preoccupations regarding the effects of capital movements on real exchange rates. To the extent that capital inflows are genuinely long term, and especially if they help finance investment projects in the tradables sector, the change in the RER will be a "true equilibrium" phenomenon, and should recognized by such by implementing the required adjustment resource allocation.

\section{Concluding Remarks}

This paper has dealt with some of the most important aspects of the recent macroeconomic adjustment process in Latin America, with especial emphasis on the relationship between stabilization and trade reform. The analysis concentrated on the 198692 period, and focused on six fundamental and interrelated issues: (1) policies undertaken to reduce the foreign debt burden; (2) efforts to reduce fiscal imbalances and the inflation tax, including the revenue impact o ftariff reduction; (3) the conduct of credit policy in the aftermath of the debt crisis; (4) the role of exchange rate policy in macroeconomic adjustment; and (5) the pressure that real exchange rate appreciation has put on policy makers. Throughout the discussion the need to establish credible macroeconomic policies was emphasized.

In the mid-1980s the sheer magnitude of debt payments represented a major obstacle for countries embarking on adjustment. Many countries were facing a debt overhang situation, where policymakers did not perceive direct benefits from the market oriented reforms. This situation was significantly altered in March of 1989 when the Brady Plan, 
which called for voluntary debt reduction agreements between banks and debtor countries, was implemented. The Brady Plan has provided significant breathing room to a group of Latin American nations, allowing them to substantially improve their performance through lower fiscal imbalances, higher investment and the implementation of major reforms.

The data analysis presented in this paper clearly shows that most countries in the region have made substantial progress in attaining macroeconomic equilibrium. Public sector deficits have been reduced, domestic credit expansion has been curtailed, expenditures have been cut significantly, and the tax system has been reformed in many countries. Also, in an effort to reduce the public sector deficit-and simultaneously improve efficiency-a number of countries have embarked on major privatization processes. However, in spite of this progress, a number of unresolved problems remain. First, in Brazil, the largest country in the region, fiscal disequilibrium continues to be rampant, with inflation surpassing $1,100 \%$ in 1992. Second, in many countries public finances have been brought under control through major cuts in capital expenditures. This has reduced public investment in infrastructure, somewhat jeopardizing the prospects for future growth. Third, in a number of countries the reduction in expenditures has affected social programs, including health, nutrition and education.

Regarding sequencing, our analysis shows that in reality things are significantly more complicated than in "how-to-liberalize" manuals. It was argued that in no country was the conventional wisdom "stabilize-first" sequence strictly followed. In most countries stabilization and trade reform have proceeded simultaneously, and in some - Brazil being the most prominent - the foreign sector has been subject to considerable opening, without any progress on the stabilization front. The analysis presented here suggests that, contrary to the predictions of the policy literature on the subject, the Latin American countries have not been hurt (at least until now) by following this unorthodox sequencing. This situatuation may be changing, however, as recent trends towards real exchange rate appreciation have reduced international competitiveness, and have generated some political pressures for renewed protectionism. This is particularly serious for agricultural products.

The most serious problem is that during transitions there usually is a tradeoff between using the exchange rate to guide inflation downward-the use of the exchange rate as a 
"nominal anchor" -- and using it to maintain a competitive real exchange rate position in the country. However, under some circumstances--and if accompanied by the adequate policies-the use of a fixed (or predetermined) exchange rate may be a very useful tool to reduce inflation. Care should be taken, however, to avoid situations of real exchange rate overvaluation, that could eventually lead to major disequilibria, speculative attacks, and balance of payments crises. The historical evidence of Latin American countries, as well as that of East Asian nations, suggests that in environments where there are significant terms of trade shocks, a somewhat flexible exchange rate policy accommodates the disturbances in a smoother fashion than rigid schemes.

An important question is whether the progress recently attained by most countries on the macroeconomic front will be maintained, allowing them to move towards long run macroeconomic stability. From a long run perspective, isolating fiscal policy from the extremes of the political budget cycle, where governments in office inflate in the periods preceding elections in the hope that this will generate a boom and an improvement in their political fortunes, helps sustain macroeconomic balance. The history of Latin America is replete with incidents where fiscal balance is lost and inflation takes over due to political pressures. Some countries have recently tried to deal with these issues by implementing reforms that reduce the degree of dependency of key institutions--such as the Central Bank-from short term politics. Argentina, Chile, and to some extent Columbia have already taken steps in this direction. Although it is still too early to know whether these reforms will be fully successful, there is little doubt that they constitute a move in the right direction. 


\section{APPENDIX \\ Inflationary Inertia and Nominal Exchange Rate Anchors}

In this Appendix the mechanics of exchange rate indexation and inflationary inertia are discussed. In addition the circumstances under which the adoption of nominal exchange rate anchors are expected to be successful in a stabilization program are analyzed. Issues related to credibility and a broad de-indexation program that goes beyond the exchange rate are emphasized. The analytical discussion is supplemented with an empirical analysis of three recent historical experiences with nominal exchange rate policy and inflation in Latin America: Chile, Mexico and Venezuela.

\section{Indexation, Inertia and Anchors}

Consider the case of an economy that produces two types of goods: tradables and nontradables. Tradables prices are assumed to be linked to international prices, while nontradables prices are determined by the condition that this market clears at all times. In order to focus on inflationary issues I abstract from problems related to changes in real exchange rate fundamentals, such as terms of trade, the degree of protection and capital flows. ${ }^{37}$ I assume that initially the country follows a crawling peg exchange rate system, where the exchange rate rule consists of adjusting the nominal exchange rate by a proportion $\phi(\phi \leq 1)$ of lagged inflation differentials. I also assume that wages are adjusted according to a rule that includes lagged inflation as well as expected future inflation. Monetary policy is assumed to be passive and to accommodate inertial inflationary forces. This stylized economy, which captures, for example, some of the most salient aspects of many Latin American countries in the 1980 s, can be depicted by the simple set of equations:

$$
\begin{aligned}
& \pi_{i}=\alpha \pi_{n}+(1-\alpha) \pi_{N h} \\
& \pi_{T}=E_{n-1}\left(d_{t}+\pi_{T}^{*}\right) \\
& d_{l}=\phi\left(\pi_{t-1}-\pi_{T-1}^{*}\right)
\end{aligned}
$$

\footnotetext{
${ }^{37}$ On these issues see Edwards (1989b). The discussion that follows draws partially on Edwards (1993a).
} 


$$
\begin{aligned}
& N^{D}\left(P_{N} / P_{T}, Z\right)=N^{s}\left(W / P_{N}\right) \\
& W_{l}=\sum_{k=1}^{K} \gamma_{k} \pi_{L}+\sigma \pi_{i}^{0}
\end{aligned}
$$

where the following notation has been used:

$\pi_{8}=$ rate of change of the domestic price level;

$\pi_{\mathrm{Tt}}=$ rate of change of the price of tradables in domestic currency in period $t$.

${ }^{\pi} \mathrm{Nt}=$ rate of change of nontradable prices in period $\mathrm{t}$;

$d_{\mathbf{t}}=$ rate of devaluation in period $\mathrm{t}$;

$\pi_{\mathrm{t}}^{*}=$ rate of world inflation in period $\mathrm{t}$;

$\mathrm{E}_{\mathrm{t}-1}=$ expectations operator, where expectations are assumed to be formed in period $t-1$;

$\mathrm{w}=$ rate of change in nominal wages;

$\mathrm{Z}_{\mathrm{h}}=$ index of aggregate macroeconomic policies, which includes monetary expansion beyond passive accommodation of past inflation;

$\mathbf{N}^{\mathrm{D}}, \mathbf{N}^{\mathrm{s}}=$ demand and supply for nontradables;

$\pi_{i}^{0}=$ expected inflation in period $t$

$\phi, \gamma_{k}=$ parameters that measure the degree of indexation in this economy;

$\sigma \quad=$ parameter that determines the importance of expected inflation in the wage rule.

Equation (3) says that the domestic rate of inflation is a weighted average of tradables and nontradables inflation. Equation (4) states that the law of one price holds 
ex-ante, and that the change in the domestic price of tradables is equal to the expected change in the exchange rate plus the expected rate of world inflation. ${ }^{38}$

Equation (5) is the devaluation rule, and states that the exchange rate is adjusted in a proportion $\phi$ of inflation rate differentials. If $\phi=1$ we have a typical Purchasing-Power-Parity rule, where the rate of devaluation is equal to (lagged) inflation rate differentials. This type of policy has sometimes been referred to as a "real target" approach. ${ }^{39}$ Equation (6) is the market clearing condition for nontradables. The demand for nontradables is assumed to depend on relative prices $\left(\mathbf{P}_{\mathrm{N}} / \mathrm{P}_{\mathrm{T}}\right)$ and on aggregate demand $\left(\mathrm{Z}_{\mathrm{T}}\right.$; the supply of nontradables is assumed to be a function of real product wages. Finally, equation $(7)$ is the wage adjustment rule, and states that wage increases depend on two factors: lagged inflation up to $\mathrm{K}$ periods, and expected future inflation. It is further assumed that $\left(\Sigma \gamma_{k}+\sigma\right) \leq 1$. The special case when $\sigma=0$ and $\Sigma \gamma_{k}=1$ corresponds to a situation where there is $100 \%$ backward looking wage indexation. In equation $(7)$ the value of $K$ will determine the degree of inflationary "memory" of this economy. Although in equation (7) w stands for the rate of change of nominal wages, it is perhaps more useful to think this variable captures a broader category of "other" costs. In that sense, then, the

${ }^{38}$ The presence of the expectations operator reflects the assumption that the domestic price of tradables is set before the rate of devaluation or world inflation are observed.

${ }^{39}$ This, however, is a somewhat misleading name since it is used to denote two quite different policies. While some authors refer to a strict PPP rule as a "real targets" policy, others define this "real target" as a policy aimed at accommodating changes in RER fundamentals. See Corden (1990). 
coefficients $\gamma_{k}$ can be interpreted as summarizing the degree of indexation of nonexchange rate contracts in the economy..$^{40}$

This model can be solved in order to find an expression for the dynamics of inflation. In order to simplify the discussion, consider the case when wages are adjusted according to inflation in the last period only $(K=1)$. Further, assume that the wage adjustment rule ( 7$)$ is a strict weighted average of past inflation and expected inflation. That is, in equation (T) $\sigma=1-\gamma$. Before solving the model it is necessary to make an assumption regarding inflationary expectations. I consider the case of rational expectations where actual realizations of inflation in period $t$ differ from the expectations formed at the beginning of that period by a random term $\mu: \pi_{i}=\pi_{i}+$ $\mu_{4}$

After manipulating equations (3) through ( 7 ) the dynamics of domestic inflation can be written as the following first order difference equation: ${ }^{41}$

$$
\pi_{1}=a_{1} \pi_{i-1}+a_{2} \pi_{i-1}^{*}+a_{3} z_{2}+\mu^{\prime}
$$

where:

$$
\begin{aligned}
& a_{1}=\frac{(\eta+\alpha \epsilon) \phi+\epsilon(1-\alpha) \gamma}{(\eta+\epsilon \alpha)+\epsilon(1-\alpha) \gamma} \\
& \alpha_{2}=\frac{(\eta+\alpha \epsilon)(1-\phi)}{(\eta+\epsilon \alpha)+\epsilon(1-\alpha) \gamma}
\end{aligned}
$$

\footnotetext{
${ }^{40}$ Notice that in this model no explicit expression has been included for the rate of growth of domestic credit. This responds to the assumption that the monetary authorities follow a passive credit policy that accommodates the inertial inflation.

"In obtaining (8) I also assumed that $E_{21}\left(\pi_{T}^{*}\right)=x_{T-1}^{*}$.
} 


$$
\alpha_{3}=\frac{-\delta(1-\alpha)}{(\eta+\alpha \epsilon)+\epsilon(1-\alpha) \gamma}
$$

and where $\eta$ is the demand elasticity of nontradables with respect to relative prices $(\eta<0), \epsilon$ is the supply elasticity of nontradables with respect to the real product wage $(\epsilon<0), \delta$ is the demand elasticity of nontradables with respect to aggregate demand pressures, and $\mu^{\prime}$ is an error term related to $\mu$.

In equation (8) coefficient $a_{1}$ provides a measure of the degree of inertia of domestic inflation. The closer is $a_{1}$ to unity the more persistent will inflation be, and the higher the degree of inertia. As can be seen from $a_{1}$ in equation (8), the degree of inertia in the economy will depend on the different elasticities involved and on the indexation parameters $\phi$ and $\gamma^{42}$ Under full lagged indexation of the exchange rate-that is, $\phi$ equal to one- the coefficient of $\pi_{t-1}$ will become unity $a_{1}=1$, and the system will have no anchor. The time series of domestic inflation will exhibit a unit root, and inflation could explode as a result of exogenous, or aggregate demand shocks. Also, according to this equation a reduction in the rate of exchange rate indexation $\phi$ will result in a decline in the value of $a_{1}$ and, thus, in a reduction in the degree of inflationary inertia in the economy. This, of course, has been the rationale for adopting nominal exchange rate anchor policies in a number of countries. According to equation (8), if indexation is totally eliminated, and both $\phi$ and $\gamma$ become simultaneously equal to zero, domestic inflation will immediately converge

\footnotetext{
${ }^{42}$ Recently a number of authors have discussed alternative ways of measuring the degree of persistence in the time series of GNP (Cochrane, 1988). Much of this recent discussion has centered on measuring persistence in non-stationary series.
} 
to world inflation. ${ }^{43}$ This situation corresponds to a Poincare-type stabilization program. ${ }^{4}$ Notice, however, that if after the nominal exchange rate is fixed $(\phi=0)$ some degree of wage indexation remains $(\gamma>0)$, there will still be some inertia and the real exchange rate will be subject to consistent appreciation during the transition process. In a sense, then, the authorities face a tradeoff where, on the one hand, the exchange rate anchor will reduce inertia, and, on the other hand, it will generate a loss of international competitiveness.

An important assumption in the nominal exchange rate anchors approach to disinflation is that the adoption of a fixed nominal exchange rate is a credible policy and that the public believes that, from the date of the new policy announcement, the coefficient $\phi$ will remain lower. ${ }^{45}$ In fact, one of the most commonly used arguments for favoring nominal exchange rate anchors over monetary anchors has to do with credibility. It has been argued that since nominal exchange rates are more visible, they provide a more credible policy than if a constant level of monetary base is announced. ${ }^{46}$ In terms of the model presented above, it follows from equation (8) that if the nominal exchange rate anchors policy is credible, we would empirically observe a structural break in the dynamic properties of inflation. This structural break would indeed take place at-or around-the moment the nominal anchor is imple-

${ }^{43}$ This again assumes that aggregate demand measures have been eliminated $\left(z_{1}=0\right)$.

${ }^{4}$ See Sargent (1983).

${ }^{45}$ See Agenor and Taylor (1992) for a survey on alternative ways to empirically test for credibility effects.

${ }^{46}$ See Bruno (1991) for related discussions. 
mented. From that point in time onward, the coefficient of lagged inflation in an equation of the type of (8) should decline, reflecting the reduction in the degree of persistence in the inflationary process. Of course, this assumes that the structural roots of inflation-fiscal imbalance and monetary creation-have been controlled by the economic authorities. If, however, the nominal anchor policy lacks credibility, and the public has doubts regarding the extent to which the government will stick to the new policy, the estimated degree of inertia in equations of the type of (8) will not be significantly affected by the adoption of the nominal exchange rate anchor. ${ }^{n}$ Empirically, there are a number of possible ways to investigate whether the adoption of exchange-rate-based stabilization programs have changed inertia. Two approaches used above are: (1) the use of interactive dummy variables to test for structural breaks in coefficient $a_{1}$ in equation (8) at the time (or around the time) of the policy change; and (2) the estimation of equation (8) using varying coefficient techniques. Exchange Rates and Inflationary Inertia in Chile and Mexico

In this subsection data on Chile, Mexico and Venezuela are used to investigate the relationship between exchange rate policy and inflationary inertia. These three countries provide interesting and contrasting lessons. Chile and Mexico used the nominal exchange rate as an anchor in their disinflation programs of the 1970s and 1980s. Venezuela, on the other hand, ended a long experience with fixed exchange

\footnotetext{
7 Edwards and Sturzenegger (1992) provide a model with endogenous credibility of the nominal exchange rate anchor.

${ }^{48}$ See Agenor and Taylor (1992).
} 
rates in 1989, when it devalued its currency and adopted a managed exchange rate system.

Chile: In the late 1970s, and after having eliminated a stubbom fiscal deficit, Chile adopted an exchange rate based stabilization program. Initially-from February 1978 to June 1979-the program consisted of a preannounced declining rate of devaluation of the domestic currency. In June 1979, with inflation standing at an annual rate of $34 \%$, the government put an end to the system of a preannounced declining rate of devaluation and fixed the nominal exchange rate at 39 pesos per dollar. When the tablita was adopted in early 1978, and again when the peso was pegged to the dollar in June of 1979 , it was decided not to alter the wage indexation mechanism, which at that time was characterized by $100 \%$ adjustment to lagged price increases.

In order to investigate empirically the way in which the adoption of a nominal exchange rate anchor affected the degree of inflationary inertia in Chile, equations of the following type using quarterly data were estimated:

$$
\pi_{i}=b_{0}+b_{1} \pi_{i-1}+b_{2}\left(D \pi_{k-1}\right)+b_{3} \pi_{i-1}^{*}+b_{1} z_{-1}+\mu_{1}
$$

where the variable $D$ is a dummy that takes the value of one for the period when the nominal exchange anchor is in place and zero otherwise. If the anchors program is effective and credible the estimated coefficient of $b_{2}$ should be significantly negative, indicating that this policy successfully reduced the degree of inertia in the system. Moreover, in the extreme case of a Poincare style disinflation, inertia should disappear 
at the time the new policy is put in place, and $\left(b_{1}+b_{2}\right)$ should not be significantly different from zero.

In the case of Chile, two dummies were used: the first one (DC1) has a value of one between the second quarter of 1978 , when the preannouncement of the declining rate of devaluation was first adopted and the first quarter of 1982 , the last quarter when the nominal anchors approach was in effect. The second dummy (DC2) takes a value of one between the third quarter of 1979 and the first quarter of 1982 . That is, D2 covers the period when the nominal exchange rate was strictly fixed.

In the estimation of equation (13) $\pi^{*}$ was defined as the quarterly rate of U.S. inflation and ${z_{11}}_{1}$ as the rate of growth of domestic credit. The raw data were taken from the IFS tape. Table A.1 contains the results obtained using OLS. The results obtained are quite interesting. In equations (13.1) and (13.2), the interactive dummies are net significant and, in addition, have a positive sign. This indicates that the implementation of an exchange rate rule in 1978-79 did not alter the degree of inflationary inertia in Chile. These results could be the consequence of a combination of factors, including the fact that the nominal anchor was not credible and that wage rate indexation was left intact during this period.9 ${ }^{49}$ These results suggest that the

49 In order to further test whether the adoption of the fixed exchange rate in June of 1979 had an effect on the inflation process, a number of tests on the structural stability of the inflation equations were computed. If indeed the shift from an accommodating adjustable exchange rate regime to a rigidly predetermined one is credible, it would be expected that the inflation equation would capture a change in regime. These stability tests were supportive of the dummy variable results reported previously, and showed no structural break in the inflation equation. For example, in the case of equation (13), the chi-square statistic for structural stability had a value of $\chi^{2}(6)=2.03$, indicating that there is no evidence of a change in the inflationary regime in mid-1979. 
adoption of a predetermined exchange rate in Chile in 1978-79 was not associated with a change in the nature of the inflationary process that one expects from a credible nominal exchange rate anchor policy. In particular, expectations, backward wage rate adjustment practices and other contract practices (e.g., indexation) do not seem to have been affected in a significant way by the reform in the exchange rate system. As a consequence, the degree of inflationary inertia remained unchanged after the adoption of the exchange rate based program of the late 1990 s. 
TABLE A.1

Exchange Rates, Indexation and Inflationary Inertia in Chile

\begin{tabular}{|c|c|c|}
\hline & $(\mathrm{Eq}, 13.1)$ & (Eq. 13.2) \\
\hline Time Period & $74.1-82.1$ & $74.1-82.1$ \\
\hline Constant & $\begin{array}{c}-0.041 \\
(-1.344)\end{array}$ & $\begin{array}{c}-0.049 \\
(-1.397)\end{array}$ \\
\hline$x_{t-1}$ & $\begin{array}{c}0.750 \\
(12.993)\end{array}$ & $\begin{array}{r}0.756 \\
(10.317)\end{array}$ \\
\hline $\mathrm{DC} 1 * \pi_{2-1}$ & $\begin{array}{c}0.019 \\
(0.688)\end{array}$ & - \\
\hline $\mathrm{DC} 2 * \pi_{L-1}$ & - & $\begin{array}{c}0.025 \\
(0.430)\end{array}$ \\
\hline$\pi_{t-1}^{*}$ & $\begin{array}{c}0.236 \\
(1.415)\end{array}$ & $\begin{array}{c}0.477 \\
(1.378)\end{array}$ \\
\hline$\hat{z}_{21}$ & $\begin{array}{c}0.288 \\
(4.812)\end{array}$ & $\begin{array}{c}0.285 \\
(4.737)\end{array}$ \\
\hline $\bar{R}^{2}$ & 0.970 & 0.969 \\
\hline DW & 2.042 & 2.036 \\
\hline
\end{tabular}

"t-statistics in parentheses. 
Mexico: As pointed out in the body of the paper, in 1986-87 the Mexican government embarked on an ambitious stabilization and reform program aimed at regaining price stability, deregulating the economy and opening foreign trade to international competition. During 1988 the exchange rate was fixed relative to the U.S., and from 1989 onward the rate of devaluation of the peso was preannounced. As in the case of Chile, and in an effort to guide expectations downwards, the rate of devaluation was deliberately set below the rate of ongoing inflation. In successive revisions of the program the preannounced rate of adjustment of the nominal rate was reduced downward. These successive reductions in the preannounced rate of change of the nominal exchange rate are equivalent to reductions in the value of coefficient $\phi$ in equation (5). As discussed in Edwards (1991), in Mexico incomes policies became a central element of the anti-inflationary package, supplementing the exchange rate rule and the fiscal adjustment. Indeed, in late 1987 with the establishment of the Pacto de Solidaridad, unions, entrepreneurs and the government worked out a politic and economic plan for defeating inflation, where price and wage guidelines became important elements of this program. ${ }^{\text {so }}$

In the estimation for Mexico the dummy variable DM was defined with a value of one between the second quarter of 1988, when the Pacto de Solidaridad was enacted, and the second quarter of 1990 . The rate of growth of narrowly defined money was used as a measure of aggregate demand pressures. In every equation estimated for Mexico the coefficient of (DM $x_{i 1}$ ) was significantly negative, indicating that the adoption of the preannounced exchange rate system and the other policies in the Pacte were credible, significantly changing the dynamics of inflation. The following result was obtained for 1979 Q1 through 1990 Q2:

${ }^{50}$ It is crucially important to point out, however, that the adoption of incomes policies in Mexico took place two years after the fiscal accounts had been balanced. See Beristain and Trigueros (1990) for a useful description. This is, in fact, a very important difference between the Mexican program and the heterodox stabilization programs of Argentina, Brazil and Peru. 


$$
\begin{aligned}
& \pi_{t}=\underset{(-3.546)}{-0.060}+\underset{(15.119)}{0.896} \pi_{t-1}-\underset{(-4.559)}{0.194}\left(\mathrm{DM} \pi_{t-1}\right)+\underset{(1.726)}{0.698} \pi_{t-1}^{*} \\
& +\underset{(2.789)}{0.179} \hat{\mathrm{Z}}_{\mathrm{(}}+\underset{(2.476)}{0.220} \hat{\mathrm{Z}}_{\mathrm{t}-1}+\underset{(1.764)}{0.144} \hat{\mathrm{Z}}_{\mathrm{t}-2}, \begin{array}{l}
\overline{\mathrm{R}}^{2}=0.945 \\
\mathrm{DW}=1.828
\end{array} \\
& \text { Period: } 79 \mathrm{Q} 1-90 \mathrm{Q} 2
\end{aligned}
$$

Formal tests for the stability of the regression as a whole show that the dynamics of inflation in Mexico experienced a structural break in the first quarter of 1988, when the exchange-rate-based and the Pacto de Solidaridad were enacted. The $x^{2}(0)$ statistic for structural stability tumed out to be equal to 44.2 , rejecting the null hypothesis that there was no structural break in the first quarter of 1988.

The contrasting results between Chile and Mexico strongly suggest that it is not enough to adopt a nominal exchange rate anchor to alter the inertial nature of the inflationary process. As the Chilean results show, it is possible to have such a system in place for a considerable period of time without inflicting a serious dent in the dynamics of inflation. To the extent that the public does not perceive the new policy as credible, pricing behavior and contract clauses will not be altered in any significant way, and the ingrained aspects of inertial inflation will continue. ${ }^{31}$ Although it is not possible to extract from these data the exact underlying macroeconomic reasons for the differences in effectiveness of these two programs, it is possible to speculate that the incomes policies implemented in Mexico alongside the pegged nominal exchange rate

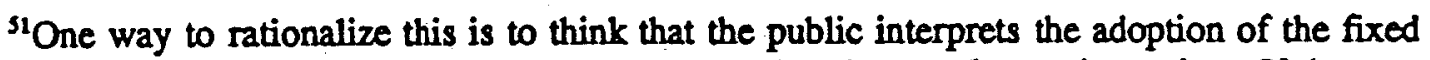
rate as a weak commitment, which can be abandoned under certain contingencies. If the private sector perceives that these contingencies are very permissive, the degree of commitment associated with the change in exchange rate regime will be very low, or nonexisting.
} 
provided a broad sense of coherence to the stabilization program. On the contrary, the continuation-and even reinforcement-of the lagged wage indexation rule gave contradictory signals to the private sector in Chile. 


\section{REFERENCES}

Agenor, P. and Taylor, M.; "Testing for Credibility Effects", IMF Staff Papers, Vol. $39,1992$.

Alesina, A.; "Macroeconomics and Politics", in Fischer, S. (ed.), NBER Macroeconomics Annual, Cambridge, MTT Press, 1988.

- and Drazen, A.; "Why Are Stabilizations Delayed?", American Economic Review, Vol. 81, No. 5, December 1991.

Aschauer, D.; "Does Public Capital Crowd Out Private Capital?", Joumal of Monetary Economics, Vol. 24, No. 2, 1989.

Bailey, M.; "The Welfare Cost of Inflationary Finance", Joumal of Political Economy, Vol. 64, No. 2, March 1956.

Barro, R.; "Are Government Bonds Net Wealth?", Loumal of Political Economy, Vol. 82, No. 6, December 1974.

Beristain and Trigueros; "Mexico", in Williamson, J. (ed.), Latin American Adjustment: How Much Has Happened?, Washington, D.C., Institute for International Economics, 1990.

Bhagwati, J.; Eoreign Trade Regimes and Economic Development: Anatomy and Consequences of Exchange Control Regimes, Cambridge, Ballinger, 1978.

Boskin, M.; "Taxation, Savings, and the Rate of Interest", Loumal of Political Economy, Vol. 86, Supplement, 1978.

Bruno, M.; "High Inflation and the Nominal Anchors of an Open Economy", Princeton Essays in International Finance No. 183, June 1991.

Calvo, G.; "On the Time Consistency of Optimal Policy in a Monetary Economy", Econometrica, November 1978.

- ; "Controlling Inflation: The Problem of Non-indexed Debt", IMF Working Paper No. 29, Washington, D.C., 1988.

_. ; "Exchange Rate-Based Stabilization Under Imperfect Credibility", IMF Working Paper No. 77, 1991.

- Leiderman, L. and Reinhardt, C.; "Capital Inflows and Real Exchange Rate Appreciation", IMF Working Paper No. 62, Washington, D.C., 1992. 
Cardoso, E. and Dornbusch, R.; "Brazilian Debt Crises: Past and Present", in Eichengreen, B. and Lindert, P. (eds.), The International Debt Crisis in Historical Perspective, Cambridge, MIT Press, 1990.

CEPAL; Balance Preliminar de la Economía de América Latina y el Caribe, Santiago, Chile, 1992a.

CEPAL; Equidad y Transformación Productiva: Un Enfoque Integrado, Santiago, Chile, $1992 \mathrm{~b}$.

Cochrane, J.; "How Big is the Random Walk in GNP?", Joumal of Political Economy, Vol. 96, 1988.

Corbo, V. and Schmidt-Hebbel, K.; "Public Policies and Savings in Developing Countries", Joumal of Deyelopment Economics, Vol. 36, No. 1, 1991.

Corden, W. M.; "Monetary Integration", Princeton, New Jersey, Princeton Essays in International Finance No. 93, April 1972.

; "Macroeconomic Policy and Growth: Some Lessons of Experience" Proceedings of the World Bank Annual Conference on Development Economics, Washington, D.C., 1990.

Devarajan, S. and Rodrik, D.; "Do the Benefits of Fixed Exchange Rates Outweigh Their Costs? The CFA Zone in Africa", in Goldin, I. and Winters, A. (eds.), Open Economies: Structural Adjustment and Agriculture, Cambridge, CEPR / Cambridge University Press, 1992.

Dombusch, R.; "Credibility and Stabilization", Quarterly Joumal of Economics, Vol. 107, No. 3, August 1991.

; "Lessons from Experiences with High Inflation", The World Bank Economic Review, Vol. 6, No. 1, 1992.

and Fischer, S.; "Moderate Inflations", World Bank Economic Review, Vol. 7, No.1, January 1993.

Eaton J.; "Sovereign Debt: A Primer" The World Bank Economic Review, Vol. 7, No. 2, 1993.

Edwards, S.; "The Order of Liberalization of the External Sector in Developing Countries", New Jersey, Princeton Essays in International Finance No. 156, December 1984. 
; "Exchange Rate Misalignment in Developing Countries", The World Bank Research Observer, Vol. 4, No. 1, $1989 \mathrm{~b}$.

; "Capital Flows, Foreign Direct Investment, and Debt-Equity Swaps in Developing Countries", in Siebert, H. (ed.), Capital Flows in the World Economy, Tubingen, JBC Mohr, 1991.

; "The Sequencing of Structural Adjustment and Stabilization", San Francisco, International Center for Economic Growth Occasional Paper No. 34, 1992.

- ; "Exchange Rates as Nominal Anchors", Weltwirtschaftliches Archiv, Vol. 129, No. 1, 1993 a.

; "Exchange Rates, Inflation and Disinflation: Latin American Experiences", NBER Working Paper No. 4320, Cambridge, Mass., $1993 \mathrm{~b}$.

_. Exchange Rate Misalignment in Developing Countries, Baltimore, Johns Hopkins University Press, 1988.

Policy in Developing Countries, Cambridge, MT Press, 1989a.

; Latin America A Decade After the Crisis, Manuscript prepared to the Latin American and the Caribbean Region Division, World Bank, 1993.

and Cox-Edwards, A.; "The Chilean Economy", Washington, D.C., Library of Congress, 1993.

and Sturzenegger, F.; "Endogenous Indexation and the Role of Credibility", Los Angeles, University of Califomia, mimeo, 1992.

and Tabellini, G.; "Explaining Inflation and Fiscal Deficits in Developing Countries", Journal of Intemational Money and Finance, Supplement 1991.

and van Wijnbergen, S.; "The Welfare Effects of Trade and Capital Markets Liberalization", International Economic Review, Vol. 27, February 1986.

Fischer, S.; "Issues in Medium-Term Macroeconomic Adjustment", World Bank Research Obseryer, Vol. 1, No. 2, 1986.

; "Recent Developments in Macroeconomics", Economic Joumal, Vol. 98, No. 2, June 1988. 
Fleisig, H.; "Infrastructure and Economic Growth in Latin America", LAC mimeo, World Bank, October 1992.

Flood, R. and Isard, P.; "Monetary Policy Strategies", IME Staff Papers, Vol. 36, No. 3, September 1989.

Fontaine, J.; "The Chilean Economy in the Eighties: Adjustment and Recovery", in Edwards, S. and Larrain, F. (eds.), Debt. Adjustment and Recovery, Oxford, Basil Balckwell, 1989.

Friedman, M.; "Government Revenue From Inflation", Joumal of Political Economy, Vol. 79, No. 4, July 1971.

Fry, M.; Money. Interest and Banking in Economic Development, Baltimore, Johns Hopkins University Press, 1988.

Gelb, A.; "Financial Policies, Growth and Efficiency", Country Economics Department Working Paper No. 202, World Bank, 1989.

Giovannini, A.; "The Interest Elasticity of Savings in Developing Countries: The Existing Evidence", World Development, Vol. 11, July 1983.

Harberger, A.; "Observations on the Chilean Economy, 1973-1983", Economic Development and Cultural Change, Vol. 33, No. 3, April 1985.

International Monetary Fund; World Economic Outlook, Washington, D.C., 1985, 1992.

Kamin, S.; "Argentina's Experience With Parallel Exchange Markets: 1981-1990", International Finance Discussion Papers No. 407, Board of Govemors of the Federal Reserve System, August 1991.

Kessel, G.; "El Sector Petroquimico Mexicano ante la Integracion del Mercado Norteamericano", in ITAM, Mexico y el Tratade Trilateral de Libre Comercio, Mexico, McGraw-Hill, 1992.

Krueger, A.; Eoreign Trade Regimes and Economic Development: Liberalization Attempts and Consequences, Cambridge, NBER, 1978.

; Trade and Employment in Develoging Countries, Chicago, University of Chicago Press, 1981.

; "Trade Policies in Developing Countries", in Jones, R. and Kenen, P. (eds.), Handbook of International Economics, Amsterdam, North-Holland, 1985. 
1990.

Krugman, P.; "A Model of Balance of Payments Crises", Loumal of Money, Credit and Banking, Vol. 11, No. 3, August 1979.

Kydland, F. and Prescott, E.; "Rules Rather Than Discretion: The Inconsistency of Optimal Plans", Joumal of Political Economy, Vol. 85, No. 3, June 1977.

McKinnon, R.; "The Order of Economic Liberalization: Lessons from Chile and Argentina", Camegie-Rochester Conferences in Public Policy, Vol. 17, Autumn 1982.

; The Order of Economic Liberalization: Financial Control in the Transition to a Market Economy, Baltimore, Johns Hopkins University Press, 1991.

Michaely, M., Choksi, A., and Papageorgiu, D. (eds.); Liberalizing Foreign Trade, New York / Oxford, Basil Blackwell, 1991.

Persson, T. and Tabellini, G.; Macroeconomic Policy. Credibility and Politics, New York, Harwood, 1990.

Razin, A. and Svensson, L.; "Terms of Trade and the Current Account", Joumal of Political Economy, Vol. 91, February 1983.

Sargent, T.; "Stopping Moderate Inflation: The Methods of Poincare and Thatcher", in Dormbusch, R. and Simonsen, M. (eds.), Inflation. Debt and Indexation, Cambridge, Mass., MIT Press, 1983.

Shaw, E.; Einancial Deepening in Economic Development, New York, Oxford University Press, 1973.

Williamson, J.; "Advice on the Choice of an Exchange Rate Policy", in Claasen, E. (ed.), Exchange Rate Policies in Developing and Post-Socialist Countries, San Francisco, ICS Press, 1991.

(ed.); Exchange Rate Rules: The Theory, Performance, and Prospects of the Crawling Peg, New York, St. Martin's Press, 1981.

World Bank; The East Asian Miracle, Washington, D.C., 1993. 